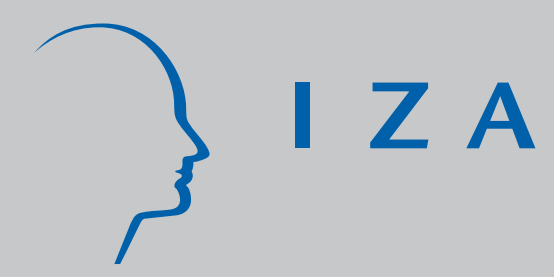

IZA DP No. 2509

Poverty, Undernutrition, and Child Mortality: Some Inter-Regional Puzzles and their Implications for Research and Policy

Stephan Klasen

December 2006 


\title{
Poverty, Undernutrition, and Child Mortality: Some Inter-Regional Puzzles and their Implications for Research and Policy
}

\author{
Stephan Klasen \\ University of Göttingen \\ and IZA Bonn
}

Discussion Paper No. 2509

December 2006

\author{
IZA \\ P.O. Box 7240 \\ 53072 Bonn \\ Germany \\ Phone: $+49-228-3894-0$ \\ Fax: +49-228-3894-180 \\ E-mail: iza@iza.org
}

\begin{abstract}
Any opinions expressed here are those of the author(s) and not those of the institute. Research disseminated by IZA may include views on policy, but the institute itself takes no institutional policy positions.

The Institute for the Study of Labor (IZA) in Bonn is a local and virtual international research center and a place of communication between science, politics and business. IZA is an independent nonprofit company supported by Deutsche Post World Net. The center is associated with the University of Bonn and offers a stimulating research environment through its research networks, research support, and visitors and doctoral programs. IZA engages in (i) original and internationally competitive research in all fields of labor economics, (ii) development of policy concepts, and (iii) dissemination of research results and concepts to the interested public.
\end{abstract}

IZA Discussion Papers often represent preliminary work and are circulated to encourage discussion. Citation of such a paper should account for its provisional character. A revised version may be available directly from the author. 


\section{ABSTRACT \\ Poverty, Undernutrition, and Child Mortality: Some Inter-Regional Puzzles and their Implications for Research and Policy}

This paper examines the relationship between measures of income poverty, undernourishment, childhood undernutrition, and child mortality in developing countries. While there is, as expected, a close aggregate correlation between these measures of deprivation, the measures generate some inter-regional paradoxes. Income poverty and child mortality is highest in Africa, but childhood undernutrition is by far the highest in South Asia, while the share of people with insufficient calories (undernourishment) is highest in the Caribbean. The paper finds that standard explanations cannot account for these interregional paradoxes, particularly the ones related to undernourishment and childhood undernutrition. The paper suggests that measurement issues related to the way undernourishment and childhood undernutrition is measured might play a significant role in affecting these inter-regional puzzles and points to implications for research and policy.

JEL Classification: I1, I3, O1

Keywords: millennium development goals, undernutrition, child mortality, poverty

Corresponding author:

Stephan Klasen

Department of Economics

University of Göttingen

Platz der Göttinger Sieben 3

37073 Göttingen

Germany

E-mail: sklasen@gwdg.de

\footnotetext{
* This paper benefited greatly from helpful comments from and discussions with Shanta Devarajan, Jean Drèze, Michael Grimm, Ravi Kanbur, John Komlos, Inmaculada Martinez-Zarzoso, Mark Misselhorn, Mercedes de Onis, Siddiqur Osmani, David Pelletier, Amartya Sen, Peter Svedberg, and participants at various conferences and workshops. I want to thank Elke Büsing and Julia Hagenberg for assembling the data set. I also want to thank Mark Misselhorn for his assistance with assessing the sensitivity of the new reference standard. Funding from the German Science Foundation in support of this work is gratefully acknowledged.
} 


\section{Introduction}

Economic development is about improving the quality of life of people in developing countries. While there are many ways to conceptualize quality of life and its constituent elements (e.g. Sen, 1998; UNDP, 1990; World Bank, 2000, Nussbaum and Sen, 1993), international development policy has recently focused on the Millennium Development Goals as the central guide. Among the goals directly concerned with the quality of life are goals to achieve absolute poverty reduction (using the $\$ 1$ a day poverty line), reduction in hunger, reductions in childhood undernutrition, and reductions in mortality and morbidity. In Table 1 , the poverty, nutrition and mortality goals, targets, and indicators that are of concern in this paper are listed. The income poverty target is to halve the share of the population living on less than a \$1 per capita a day between 1990 and 2015. The undernutrition target is to halve the share of the population suffering from hunger where two indicators are used. One focuses on anthropometric outcomes of children where the indicator is the share of children (aged 0-5) that are underweight (defined as having a weight for age below 2 standard deviations of an international reference standard, see below for details). The other is concerned with nutritional inputs and estimates the share of a country's population with insufficient access to calories, (with the calorie cut-off ranging from 1790 to 1880 kcal per capita per day, see Svedberg (2002)). As is now common practice, I will refer to this calorie deficiency issue as undernourishment and the previously mentioned underweight measure for children as childhood undernutrition (FAO, 2003). For each of these targets and indicators, there is a designated official source of information to monitor progress.

Apart from many studies on the determinants of these individual indicators of achievements, there is a large literature investigating the importance of income (and income growth) on these different development targets. The literature on the impact of growth on absolute poverty reduction is probably the most comprehensive and has exhaustively tackled this issue using the inherent mathematical relationship between the two (with income distribution being the key mediating factor) both theoretically as well as empirically (e.g. Bourguignon, 2003; Datt and Ravallion, 1992; Adams, 2005; Klasen and Misselhorn, 2006).

Regarding the impact of income, income poverty, and income growth on undernutrition and child mortality, theoretical considerations would suggest a close linkage. ${ }^{2}$ More resources at the household level improve the ability of household members to acquire more calories, and of parents to invest more in the nutrition and health of their children. These linkages would likely be larger in aggregated cross-country data as used below than in household-level data, as higher per capita incomes also tend to increase investments in public services in the areas of health, nutrition, water and sanitation, and social protection, ${ }^{3}$ which are other important factors influencing hunger and childhood mortality. Due to the importance of some of these other factors for childhood mortality (particularly prenatal care, vaccinations, access to clean water and sanitation services), one might also expect that the effect of incomes on mortality outcomes might be weaker than on nutrition outcomes, although this might not show up in cross-country regressions. ${ }^{4}$

Empirically, there is also a large literature that on the one hand documented the relatively close correlation between income and these non-income achievements (e.g. Pritchett and Summers, 1996; Anand and Ravallion, 1993, Anand and Bärninghausen, 2004). This relatively close correlation has

\footnotetext{
${ }^{2}$ For conceptual frameworks of the factors influencing undernutrition and child mortality, see UNICEF (1998) and Mosley and Chen (1984).

${ }^{3}$ This correlation between per capita incomes and public services is far from perfect and some very poor countries have invested a great deal in the provision of public goods (e.g. Sri Lanka, pre-reform China, or the Indian state of Kerala). For a discussion see Drèze and Sen (1989).

${ }^{4}$ In micro regressions, incomes seem to have, as expected, a larger effect on undernutrition than on child mortality (e.g. Harttgen and Misselhorn, 2006).
} 
actually motivated Devarajan et al. (2002) in their study on 'costing the MDGs' to focus on measures that would simply raise income levels enough to achieve the non-income MDGs as well. Many other studies have focused on the reasons for the lack of an even closer correlation, pointing to the important role of inequality, poverty, and the provision of public services in affecting these outcomes (e.g. Sen, 1988; Anand and Ravallion, 1993; Lipton and Ravallion, 1995; McGillivray, 2005; Klasen, 2000a). ${ }^{5}$ As expected, the impact of per capita incomes on undernutrition and child mortality in cross-country regressions is larger than that of household incomes in micro-level regression. ${ }^{6}$

At the same time, the economic literature on the linkages between the various non-income dimensions of well-being is relatively sparse. The epidemiological and public health literature suggests a large influence of undernutrition on child mortality as undernutrition increases the susceptibility to and severity of illnesses (e.g. Osmani, 1990, Pelletier, 1994). While this has also been largely confirmed in small-scale panel studies (e.g. Pelletier et al., 1993, 1994), the empirical literature on these linkages is not as strong, partly also because of a lack of socio-economic data in many of these studies, the lack of large representative panel data sets, or a range of difficult econometric problems (such as endogeneity, left out variable bias, among others). ${ }^{7}$

Partly as a result of this, there have been vigorous debates on the size of the influence of childhood undernutrition of child mortality. At one extreme is a study by Pelletier et al. (1994) claiming that some $60 \%$ of childhood deaths are directly or indirectly attributable to moderate or severe undernutrition. At the other extreme are studies by Seckler (1982) and Sukhatme (1982) claiming that moderate undernutrition (particularly moderate stunting which is low height for age) is the optimal adaptation of the body to reduced energy intake with no adverse health consequences. Most micro-level empirical evidence suggests some negative effects of moderate undernutrition and clearly identifies elevated morbidity and mortality risks for severe undernutrition, where wasting (low weight for height) is found to be particularly dangerous (e.g. Osmani, 1990; Pelletier, 1998).

While both the theoretical and empirical literature thus suggests a close linkage among these MDG indicators, I show below that these aggregate correlations hide several inter-regional paradoxes. In particular, for each indicator a different region is shown to be most seriously affected. For example, the Caribbean suffers from the highest rates of undernourishment despite comparatively low rates of income poverty, childhood undernutrition, and child mortality. In Africa, income poverty and child mortality is highest, but childhood undernutrition only moderate, while in South Asia childhood undernutrition is highest, yet income poverty, undernourishment, and child mortality rates are only moderate. Given presumed strong causal connections between these indicators of ill-being, these regional patterns seem very surprising. I also show that standard empirical models of undernutrition and child mortality are unable to account for these inter-regional puzzles and suggest that measurement issues might play a significant role in accounting for these paradoxes.

The next section first shows the close aggregate correlation between the various MDG indicators. Then it presents the inter-regional paradoxes and will show how standard empirical models are unable to explain these differences. The third section will then critically review the details of how these indicators are constructed and comment on the possible reasons for the observed interregional paradoxes. The fourth section concludes and points to a research and policy agenda emerging from these tentative findings.

\footnotetext{
${ }^{5}$ In fact, the main empirical justification for the composite Human Development Index (combining life expectancy, education, and log of per capita incomes) produced by UNDP has been the fact that income levels are an imperfect predictor of success in some of these non-income dimensions of well-being (UNDP, 2000; McGillivray, 2005).

${ }^{6}$ See for example, Smith and Haddad (1999, 2003), Klasen (2000b), and Harttgen and Misselhorn (2006).

${ }^{7}$ See Guilkey and Riphahn (1998) which tackles some of these issues using a structural model and panel data for the Philippines.
} 


\section{Aggregate Correlations and Inter-Regional Paradoxes}

I begin by showing that our analysis is consistent with the findings from the existing literature on the aggregate linkage between the various MDG indicators. To do this, I assembled a data set on absolute poverty (using the $\$ 1$ and $\$ 2$ a day poverty lines), undernourishment and childhood undernutrition, and infant and child mortality rates from the sources indicated in Table 1 and/or the World Development Indicators (WDI) and add data on PPP-adjusted real GDP per capita and female literacy rates also from WDI (World Bank, 2005). The undernourishment indicator refers to the share of the population suffering from calorie deficiency. The childhood undernutrition indicators refer to the share of children below 6 with at least moderate growth deficits (stunting), at least moderate weight for height deficits (wasting) and at least moderate weight for age deficits (underweight), with the last one being the official MDG indicator. Deficits are defined as the respective anthropometric indicator being at least two standard deviations below an international reference standard. ${ }^{8}$ I do this for two time periods one centering on the year 1990 and the other on the year $2000 .^{9}$

In Table 2 I show simple correlation coefficients between the various indicators for the year 2000 (the results for 1990 are nearly identical). The correlations between the nutrition and mortality indicators, based on between 65-120 developing countries, are all highly significant and large, and in line with our expectations. Also as expected, the correlations of all these indicators with per capita incomes are also very strong. In fact, when using log income per capita, the correlations are among the highest found in the table, suggesting that there is a concave relationship between per capital income levels and these MDG outcomes, as often found in the literature (see e.g. Anand and Ravallion, 1993; Pritchett and Summers, 1996; McGillivray, 2005). ${ }^{10}$ So there are no surprises here.

Matters are much less clear when I examine the same indicators in first differences. Table 3 shows correlation coefficients for changes in the same variables between 1990 and 2000. Now the correlations are much weaker and often not significant (though largely in the expected direction). Partly this is to be expected as the signal to noise ratio in first differences is much lower and thus measurement error reduces the observed correlations. Nevertheless, of particular note is the relatively low or absent correlations between the change in undernourishment and the other indicators in the table. Conversely, income growth continues to be significantly correlated with progress in all MDG targets (although the correlation is only significant at the $10 \%$ level with changes in stunting and underweight). While the strong correlation between income growth and

\footnotetext{
8 The method for evaluation is based on the Z-score which is defined as:
}

$Z=\frac{A I_{i}-M A I}{\sigma}$

where $\mathrm{AI}_{\mathrm{i}}$ refers to the individual anthropometric indicator (height for age, weight for height, or weight for age), MAI refers to the median of the reference population, and $\sigma$ refers to the standard deviation of the reference population (see for example Gorstein at al., 1994, WHO, 1995). Moderate (severe) undernutrition obtains whenever the Z-score is smaller than $-2(-3)$.

${ }^{9}$ Since the data on childhood undernutrition and poverty are based on household surveys that are not repeated every year in most countries, they are reported at irregular intervals. The data include the closest we could find to those two benchmark years. In addition, we do not have data for all indicators for all countries so that the sample varies slightly depending on the analysis.

10 The relationship between income poverty and the non-income MDG goals is generally somewhat weaker than with log per capita incomes, which is probably due to measurement issues related to the poverty indicator (see below). We also used different education indicators (particularly the total years of schooling measure by Barro and Lee) and found the same correlation for a slightly reduced sample. 
poverty reduction is to be expected, it is more surprising that only income growth has significant correlations with changes in undernourishement, as well as changes in all childhood undernutrition and mortality indicators.

Thus these aggregate correlations confirm, consistent with existing literature, the strong linkages between the MDG targets in levels but the correlation is much weaker and often not significant in first differences. The log of per capita income levels and GDP growth appear to be the strongest and most important predictors of the MDG targets, both in levels as well as trends over time.

Another way to look at the same data is to present regional averages. The definitions of regions used are taken from World Bank classifications and Table 4 reports on the population-weighted averages for the various indicators for each region as well as PPP-adjusted real GDP per capita (1995 prices) for 1990 and 2000. ${ }^{11}$

While also here there is a rough correspondence at the regional level between the different indicators, there are a number of rather puzzling results. If we take per capita incomes, headcount poverty, or infant and child mortality as the indicator, Sub-Saharan Africa (excluding South Africa) is by far the worst off region in all the three dimensions and the gap to the other regions has widened considerably over the 1990s. If we consider undernourishment, however, now the Caribbean has surprisingly the highest rates of caloric deficiency of all regions in the world both in 1990 as well as in 2000. ${ }^{12}$ Similarly puzzling is that South Asia has by far the highest rates of childhood undernutrition in the developing world in both years. While the difference has narrowed somewhat with Sub Saharan Africa over the decade, it is still substantial, particularly when considering wasting or underweight. Moreover, given South Asia's much better position, compared to Sub Saharan Africa, in 2000, when considering income, poverty levels or childhood mortality, one would have expected considerably lower rates of childhood undernutrition.

Figures 1 and 2 demonstrate these regional puzzles with some scatterplots. In Figure 1, the share of underweight children is related to the share of the population undernourished in 2000. While the positive correlation is clearly visible, the spread is very wide and, in line with the table, the Caribbean (and to a lesser extent, Sub-Saharan Africa) stand out with high undernourishment rates while South Asia stands out with the surprisingly high rates of childhood undernutrition, compared to their levels of undernourishment. In Figure 2, childhood undernutrition is related to under-five mortality in 2000. The positive correlation between the two variables is stronger than in Figure 1, but the regional differences remain. In particular, the second part of the regional puzzle becomes visible where South Asian countries have much lower than expected under five mortality rates, given their high reported rates of childhood undernutrition. Conversely, most Sub-Saharan African countries have higher than expected rates of under five mortality. When using data for 1990, the regional differences are even larger and they also would persist if we focused attention to rates of severe childhood undernutrition (i.e. the share of children whose weight for age is below 3 standard deviations of the international reference standard, see Klasen 2000b).

How can it be that people in the Caribbean are energy-deprived yet the children do not suffer as much from income poverty, undernutrition or child mortality, while in South Asia children suffer from widespread undernutrition yet have comparatively low mortality rates, while children in Africa appear better nourished yet die at much higher rates?

One possible answer to these puzzles would be that there are regional differences in the causal factors that would account for these differences. Thus we need to control for the most likely

\footnotetext{
11 The countries included are driven by data availability but are roughly consistent across the two periods and across the different indicators. See also note below the table.

${ }^{12}$ The five countries included are Dominican Republic, Guyana, Haiti, Jamaica and Trinidad and Tobago.
} 
determinants and see whether the regional differences disappear. In Tables 5-7 I present a number of simple regressions using the data assembled as described above. I present cross-section regressions for 2000, panel regressions using data from 1990 and 2000 where I hope to control for unobserved country effects, regressions in first differences, and pooled panel regressions using a larger data set including a wider array of covariates. ${ }^{13}$ The plan is not to provide a thorough investigation of the causes of undernourishment, childhood undernutrition, and infant and child mortality, but to see whether there are plausible candidates for explaining the above-mentioned inter-regional puzzles. In line with the literature on the subject, I consider as standard explanatory variables the log of PPP-adjusted GDP per capita, the female adult literacy rate, the total fertility rate, and the poverty headcount rate. ${ }^{14}$ It turns out that in virtually all regressions, the poverty headcount rate is not significant whenever log per capita GDP is included (presumably due to multicollinearity), and per capita GDP always has a stronger predictive power. Consequently, I drop the poverty headcount variable. I add other variables in some of the regressions as is warranted based on theoretical or empirical considerations.

The regressions of Table 5 attempt to identify determinants of undernourishment as well as changes in undernourishment. The first regression just considers the three variables for the year 2000, the next adds regional dummies, the third regresses changes in undernourishment rates on initial levels and changes of the explanatory variables (each defined as levels in 2000 minus levels in 1990), and the last one is a fixed effects panel regression. ${ }^{15}$ The explanatory power of the regressions is not particularly high and quite low in the change regression. In the first three regressions, levels and changes of per capita GDP are the only robust influence on levels and changes in undernourishment. Given that this indicator is really about the food resources a country has its disposal, this strong correlation is not surprising. In the change regression, high rates of initial undernourishment are significantly associated with declines in undernourishment. This "convergence" result is probably driven to a considerable extent by measurement error as well as the effect of temporary shocks of the left-hand side variable (e.g. a sudden food crisis), which are not well captured by the right-hand variables. The regional dummy variables generally do not add much to the explanatory power of the regressions; the Caribbean has a positive (but insignificant) effect, and the Middle East and North Africa a negative and significant effect. In the fixed effects panel regression, only the female literacy rate has a significant effect in the expected direction, but this is partly due to multicollinearity with GDP per capita. If female literacy is dropped, GDP per capita (and the total fertility rate) both have a significant influence. Also, an examination of the fixed effects reveals an average fixed effect of 11.6 percentage points for the Caribbean and -16.7 percentage points for the Middle East and North Africa, pointing to the inability to explain these two outliers.

In sum, only per capita GDP has a reasonably strong and robust influence on undernourishment rates and it appears that there are unusually high rates in the Caribbean and unusually low rates in the Middle East and North Africa not explained by the model.

Table 6 includes regressions of the determinants of childhood undernutrition. I only report regressions for underweight (insufficient weight for age). ${ }^{16}$ The first four regressions shown are

\footnotetext{
13 This data set was first used in Klasen (2000b, 2003) and has since been updated to include more recent observations.

${ }^{14}$ See Klasen (2000b) for a more detailed motivation of the variables and, for example, Osmani (1997) and Smith and Haddad (2002) for similar specifications. The focus here is not to precisely estimate the coefficients for these determinants. If one were to do so, one would have to control for possible endogeneity problems, particularly in the cross-section child mortality regressions (where several of the right-hand side variables are likely to be endogenous and would need to be instrumented).

${ }^{15}$ The Hausman test suggested fixed effects as the preferred specification.

${ }^{16}$ The regressions for wasting (insufficient weight for height) performed in general worse than the ones we present. This is not surprising given that wasting is a measure of acute undernutrition and its determinants are not well captured by our independent variables. The regressions on stunting are very similar to the underweight regressions (in terms of
} 
based on the cross-section for the year 2000, use our standard variables and also add undernourishment rates to see whether this input-related indicator (caloric deficiency) will also affect the outcome-related indicator for childhood undernutrition. ${ }^{17}$ The first regression already has a surprisingly good fit, with strong and significant influences of income and female literacy on underweight. The share of undernourished (regression 2) also has a significant impact, but the quantitative impact is small and does little to improve the fit of the overall regression. Once I include regional dummy variables, the fit of the regression (with or without undernourishment) improves considerably again, and now the fertility rate also has a positive and significant coefficient. The size of the regional dummy variables for South Asia and, to a lesser extent, East Asia and the Pacific are very large, suggesting that even controlling for all covariates, the prevalence of underweight is around 20 percentage points higher in South Asia than in Sub Saharan Africa (the omitted category). Since the difference between the two regions is only about 15 percentage points, more than that difference is 'accounted' for in the dummy variable, and thus remains unexplained. The change regression (column 5) shows a negative but smaller and only marginally significant coefficient of initial underweight rates, which is probably mostly related to measurement error. Also, increases in per capita incomes have, as expected, had a (marginally) significant impact on reducing childhood undernutrition. Other than that, there are few significant coefficients, other than a small but significant coefficient on changes in undernourishment. The regional dummy variables are mostly not significant, so that the problem of the inter-regional puzzles only appear in levels of childhood undernutrition, but not in trends over time. ${ }^{18}$

The panel regressions show a similar picture. Using random effects (as indicated by specification tests), income, female literacy, and undernourishment rates retain their significant influence, but the random effects show a distinct regional pattern with South Asia having an average random effect of 16 percentage points (with India and Bangladesh each having a 21 percentage point random effect), and East Asia also having a sizable positive and Middle East and Caribbean a sizable negative average random effect. Using fixed effect regressions imply even larger positive fixed effects in South Asia and East Asia. Thus also the panel regressions, regardless of the specification, cannot solve what has been called the 'South Asian Enigma' of inexplicably high levels of childhood undernutrition (Ramalinaswami et al., 1996), despite its ability to control for left-out variable bias using country-specific effects.

This is also confirmed when other explanatory variables are included (see regression 7). Using a slightly different data set (based on Klasen (2000b, 2003) which is much larger, stretches further back in time, but does not include the most recent years), I include as additional covariates population density (as this might be an indicator of crowding and/or might be an indicator of the relative costs and quality of available calories), malaria prevalence (using the index by Gallup and Sachs, 2001) ${ }^{19}$, access to modern sanitation, and caloric availability. Both in a pooled panel regression as well as in fixed or random effects models, the additional covariates improve the fit of the regression and are usually significant and in the right direction, but the regional fixed effects continue to display the same pattern so that also these variables are unable to account for the

\footnotetext{
goodness of fit) and often perform better than the underweight regressions. All regressions as well as the data set are available on request.

${ }^{17}$ Poverty was, once again, dropped as it was insignificant and had no influence on the other variables.

${ }^{18}$ Using stunting as the dependent variable, the change shows that stunting was (marginally) significantly reduced in South Asia and East Asia by about 6 percentage points over the 1990s, even after controlling for the other covariates, suggesting that linear growth has improved in these two regions for reasons not accounted for in the regressions. In the regressions of stunting levels, South Asia has a significant fixed effect of about 12 percentage points, and East Asia of 6 percentage points, so that the puzzle in levels is similar to the underweight indicator (but, consistent with the descriptive statistics in Table 4, somewhat smaller in size).

${ }^{19}$ The index multiplies the fraction of the population in high risk areas with the fraction of the of malaria cases that are falciparum malaria, the most malignant form. See Gallup and Sachs (2001) for more details.
} 
regional differences. ${ }^{20}$ Experimentation with a range of other variables did not change the results. Also, other cross-country literature on the topic have similarly been unable to account for the large 'South Asian’ effect (e.g. Osmani, 1997; Smith and Haddad, 1999; Brinkmann, 1997, Klasen, 2000b, 2003).

The same results obtain when using micro data regressions that allow further household-level covariates to be included. For example, Smith et al. (2003) include maternal height, female economic status, asset indices, and a range of other variables in their micro data regressions using the Demographic and Health Surveys and find that even after controlling for all of these effects the differences in childhood undernutrition between South Asia and Sub-Saharan Africa remain unexplained. Similarly, Harttgen and Misselhorn (2006) additionally include community-level variables using multi-level modeling techniques yet still are unable to explain the high prevalence of childhood undernutrition in South Asia.

In Table 7, we turn our attention to under five mortality rates. ${ }^{21}$ In the first regression, I add to our four standard variables the HIV prevalence rate as the AIDS epidemic is sure to affect mortality of AIDS-affected children, who were infected via mother-to-child transmission (see World Bank, 1997). With this simple regression, some $85 \%$ of the variation in under five mortality is already explained and all the variables have the expected signs. ${ }^{22}$ Undernourishment rates do not have an additional influence, nor do, surprisingly, rates of childhood undernutrition (regressions not shown). Adding regional dummy variables (regression 3) further improves the fit of the regression and now we have the opposite 'problem' we had with the childhood undernutrition regressions. Now South Asia, East Asia, Latin America, and the Middle East and North Africa all have large and significantly lower rates of under five mortality, compared to Sub Saharan Africa (the omitted category). But in contrast to the underweight regressions, the regional dummy variables are much smaller than the raw inter-regional differences in under five mortality, i.e. we were able to explain usually between $50-80 \%$ of the total inter-regional differences using our covariates and only the remainder is unexplained and stuck in the dummy variables.

The mortality change regression shown in the third column also has quite a good fit. High mortality countries saw a faster reduction, which may partly be driven by measurement error. In addition, it might be due to declining marginal effects of efforts to combat under five mortality, leading to higher mortality reductions in high mortality countries (see World Bank, 1993). Income growth significantly accelerated the mortality decline, while the emergence of HIV slowed it significantly. ${ }^{23}$ Surprisingly, improvements in female literacy are associated with slowing the mortality decline, which is probably related to the regional pattern of expansion of female literacy ${ }^{24}$ as well as multicollinearity with the total fertility rate. As far as regional patterns are concerned, all regions experienced significantly faster mortality reduction than Sub Saharan Africa (the omitted category), suggesting that Africa's child mortality problem is not only related to HIV/AIDS and stagnating incomes.

The (random effects) panel regression shown in column 4 also confirms the results from before. All factors have a significant influence of similar magnitude as in the cross-section regression. The estimated random effects are positive in Sub Saharan Africa and particularly high in West Africa,

\footnotetext{
${ }^{20}$ Since caloric availability was not significant, it is not included in the pooled panel regression. There are some differences in the random and fixed effects models, but not with regard to the regional differences discussed above.

${ }^{21}$ We also consider infant mortality rates where the results are very similar.

${ }^{22}$ Income poverty increases under five mortality but was not significant. See also Anand and Bärninghausen (2004) for related findings.

${ }^{23}$ The HIV prevalence rate is just the rate in 2000 rather than the change between 2000 and 1990 . Since prevalence was very low virtually everywhere in 1990, the rate in 2000 is a good proxy for the change since 1990.

${ }^{24}$ The expansion was largest in Africa where mortality decline was slowest.
} 
suggesting that there under five mortality rates are much higher than predicted by the model. Childhood undernutrition, again, has surprisingly no impact on child mortality (column 5).

Also here, some further covariates might be of use to explain high African under five mortality rates and thus I turn to the larger data set to see whether it helps explain this regional pattern. The results suggest that immunization rates and sanitation access have the expected impact (column 7), but malaria prevalence and density of doctors (not shown) do not. ${ }^{25}$ The dummy variables are similar in size but somewhat smaller in magnitude.

It is time to take stock of the many individual findings I presented here. I started by noting the inter-regional puzzles in undernourishment, childhood undernutrition, and under five mortality. Our empirical analyses of the determinants of these three phenomena suggest three messages. As far as undernourishment is concerned, it appears hard to explain levels and trends using standard variables. It also only has small of often small and/or not significant effects on underweight and child mortality. It thus appears that this indicator contains quite a lot of noise that might account for the regional quirks, particularly the high prevalence in the Caribbean (and low prevalence in the Middle East and North Africa). The childhood underweight variable seems to behave rather strangely. While plausible determinants have the expected effects, it appears impossible to explain any of the regional differences between South Asia and Sub Saharan Africa in underweight using a large set of plausible covariates and using macro or micro regressions. This puzzle exists only in levels, not in trends over time. More surprisingly, underweight rates do not seem to have a significant effect on under five mortality, once I control for other covariates. Lastly, I seem to be unable to fully explain the high rates of under-five mortality in Africa although here the problem appears much smaller than with the childhood undernutrition indicator.

It thus appears critical to examine conceptual and empirical issues surrounding the construction of the undernourishment and the childhood undernutrition indicator to see whether there are inherent conceptual or measurement problems in these indicators. This will be taken up in the next section.

\section{Conceptual and Measurement Issues regarding the Undernourishment and Childhood Undernutrition Indicators}

\section{a) Undernourishment}

Calculating the share of the population with inadequate calorie supplies is no easy undertaking. Presumably this would be best done using reliable household-level information on caloric availability (see below). FAO, however, takes a different macro approach to this issue and proceeds in three steps. ${ }^{26}$ First, it calculates per capita calorie availability in a country by estimating food production (including auto-consumption), deducting exports, adding imports, making allowances for waste and use as seed, and then transforming available food into its caloric content. After dividing by population, per capita availability of calories is computed. This is done on a three-year rolling average. In a second step, a distribution of calories among households is estimated, assuming a log normal distribution and making an estimate that takes into account inequality in food expenditures. For reasons that are not entirely clear, the regional average of the coefficient of variation is found to be around 0.3 in all regions (see Svedberg, 2002). In a third step, the average age-sex composition and activity levels are used to calculate the cut-off point which is then applied to the log-normal distribution to calculate the share of undernourished. As the second and third step

\footnotetext{
${ }^{25}$ This is in contrast to similar regressions by Anand and Bärninghausen (2004) who found a significant impact of density of doctors on child mortality. The likely reason for the difference is that we control for many more covariates, including the regional dummies, which were probably absorbed by the doctor density variable in the other study. ${ }^{26}$ See Naiken (2003) and Svedberg (1999, 2002) for a detailed discussion of the method.
} 
yield results that vary little by country, the share of undernourished is virtually entirely driven by the first step, i.e. the per capita caloric availability (Svedberg, 2002).

This method appears highly problematic for a number of conceptual and empirical reasons which have been discussed in the literature for some time (see particular FAO, 2003 and Svedberg 1999, 2002). At the conceptual level, it is very unclear what is really being measured. In particular, given that the time frame is a three year rolling average, this measure does not well capture food crises or famines, but longer-term shortages of caloric availability. Whether this has any relationship to the number of people being 'hungry' at any one point in time is open to question. Similarly, as it is a purely aggregate measure, it does not really give much guidance to policy-makers where and why the problems are particularly severe. As a purely input-oriented approach, it is also unclear what this approach says about the effective nutritional status of the population which will depend on many other things including other nutrients, disease status, etc.

Second, assuming a similar distribution of calories across countries with different mean availability is highly implausible. This would mean that in a country with low average calorie availability, a significant share of households would have to contend with levels of caloric availability that are inconsistent with survival. Conversely, in countries with a high mean availability, the coefficient of variation is likely to be much larger as richer households can and do afford (within limits) more calorie consumption (including also more waste of calories). Third, estimating energy requirements is highly complex given that it not only depends on the age-sex composition, but also on morbidity status, pregnancy status, etc. ${ }^{27}$ Thus the last two steps in the calculation appear conceptually flawed.

The biggest problems appear to come, however, from very patchy and unreliable data on food production, including little reliable information on auto-consumption, and very crude assumptions about 'waste.' It is also likely that these data problems differ greatly by regions. Many of the regional differences in caloric availability, including the low availability in the Caribbean, are likely to be due to simple data problems.

As a result, it is doubtful that these undernourishment figures can present a reliable estimate of the proportion of the population that is 'hungry' in a year. It is unclear what is being measured, it is far too aggregative a figure, it is based on patchy data and very crude assumptions, it can say little about short-term trends or between country or within country variations, and it does not help in identifying the undernourished population. It is therefore no surprise that there is a lot of noise in the data and it is difficult to understand determinants and trends in undernourishment and its relationship to other indicators of undernutrition.

\section{b) Childhood undernutrition}

In many ways the approach taken to measure childhood undernutrition has much to recommend itself. It measures effective nutritional status, not just inputs, it is built up from individual data, usually with good and transparent sampling procedures and measurement protocols (due particularly to the standardized Demographic and Health Surveys), and it focuses on children who tend to particularly vulnerable to nutritional deficiencies. It not only allows the production of aggregate indicators, but identification of particularly hard hit groups and can easily be used as a monitoring device for policy purposes. The three different indicators, stunting, wasting, and underweight also offer insights on different dimensions of nutritional problems. Wasting (low weight for height) is an indicator of acute undernutrition particularly relevant in famines and to

\footnotetext{
${ }^{27}$ Also, the approach does not consider household-level variation in the age-sex composition to calculate the cut-offs but just aggregate variation which means that this introduces a bias in the calculation if there is a correlation between mean availability and the age/sex composition at the household level.
} 
monitor acute food shortages, stunting (low height for age) an indicator of chronic undernutrition focusing on persistent nutritional deficiencies, and underweight (low weight for age) a summary indicator combining both facets.

At the same time, there are a number of problems and issues involved with interpreting these indicators. As mentioned above, these are generated by calculating a Z-score which is the difference between the relevant anthropometric indicator of a child and the median of a reference population, divided by the standard deviation of the reference population. If this Z-score is below 2 , moderate undernutrition is presumed; if it is below -3 , severe undernutrition is presumed (UNICEF, 1998).

Two points are worth noting. First, the cut-offs are chosen with a probabilistic interpretation. A Zscore of -2 suggests that, given genetic variability, there is a $95 \%$ chance that the individual child is indeed suffering from undernutrition. If this interpretation is used, the type II error of this assessment is huge, i.e. most children with a Z-score of between 0 and -2 (and quite a few with a Zscore above 0 but genetically tall or heavy parents) could well be suffering from undernutrition which would systematically underestimate childhood undernutrition at the population level. An alternative interpretation of the choice of these cut-offs is that only serious nutritional deficiencies relative to the standard should be counted as undernutrition, and thus children with a Z-score between 0 and -2 should not be included. ${ }^{28}$

Second, the calculation of the Z-score critically depends on the reference standard. Since 1978, WHO has recommended the use of a single international reference standard for all countries of the world (WHO, 1983) and this standard has been used throughout this paper. The standard used was created by the US National Center for Health Statistics and the Centers for Disease Control and is based on the interspliced experience of two populations of US children. For children under 24 months, data from a study of white, largely bottle-fed middle-class children from the longitudinal Fels study from 1929-1974 were used, while for older children the standard is based from several nationally representative sample of children in the US in the 1960s and early 1970s (WHO, 1995).

Applying this US standard worldwide implies that there are no (genetic) differences between populations in their growth and weight development between 0 and 6 years. This claim was backed up by a variety of individual studies and the editorial opinion of major medical journals (e.g. Lancet, 1984; Graitcer et al., 1981; Habicht et al, 1974). This was supported by studies showing that the difference in growth and weight gain between privileged children from developing countries and the US reference standards were very small (Martorell et al, 1988; Habicht et al, 1974; Graitcer et al, 1981; WHO, 1995; Ramalingaswami et al., 1996, Bandhari et al. 2002). This view of one reference standard for all children in the world was reiterated by a WHO Expert Committee in 1995 and has influenced the development of the new international reference standard (see below and WHO, 1995, 1999).

While this appeared to be the consensus view, it has never been fully accepted by everyone (e.g. Davies, 1988; Eveleth and Tanner, 1990; Bogin, 1988; MacFarlane, 1995). While all agree that environmental factors are much more significant than genetic differences in explaining differences in anthopometric shortfall between populations, quite a few studies suggested that genetic differences are important enough to be considered, particular for international comparisons of anthropometric shortfalls.

\footnotetext{
${ }^{28}$ In addition, interpreting a Z-score of an individual child generates further problems as there clearly are genetic influences of the parents on weight and height of their children. Thus individual children might be falsely identified as well nourished or undernourished. Thus using these cut-offs can only usefully be applied at higher levels of aggregation where presumably these inter-individual genetic differences cancel out.
} 
In this context, it should be pointed out that the preferred measure for international comparisons, the share of children below a $\mathrm{Z}$ score of -2 or -3 is highly sensitive to even small differences in the reference standard. For example, even those who favor one standard suggest that genetic differences between South Asian and US children amount to about $1 \mathrm{~cm}$ of height difference by age five (WHO, 1995). Other researchers believe that the difference is a bit larger, on the order of 1-3 cm between well-to-do children in the USA and in South Asia (Bogin, 1988; Davies, 1988; Eveleth and Tanner, 1990, MacFarlane, 1995). ${ }^{29} 1 \mathrm{~cm}$ constitutes less than $1 \%$ of the median height at age 5 for boys $(109.9 \mathrm{~cm}$ ), and even $3 \mathrm{~cm}$ would be less than $3 \%$ (WHO, 1983). In a population such as South Asia's, where about $50 \%$ of the population are stunted or underweight in 1990, a difference of only $1 \%$ in the reference standard, however, would lead to an 8 percentage point drop in the share of underweight children. If we believed the difference is 3\%, South Asia's rate of undernutrition in 1990 would have been below the rate observed for Sub-Saharan Africa in that year, where there is little evidence of a similar genetic difference in the growth of children, compared to the USA. ${ }^{30}$ Thus a large share of the South Asian undernutrition enigma would simply disappear if the reference standard differed by just a minor amount. ${ }^{31}$

Due to reasons largely unrelated to this question, ${ }^{32}$ WHO decided in 1994 to develop a new international reference standard (WHO 1999). The standard was to be based on the growth experience of children in different parts of the world but it was recommended that a single standard was to be constructed from the growth experience of children in different countries (WHO, 1995; 1999). Such a new international standard was recently published in 2006 (de Onis and Garza, 2006). It is based upon the growth and weight development of children in six countries (Brazil, Oman, Ghana, India, USA, and Norway) where a sample of children was monitored that followed WHO feeding guidelines and were not constrained by inadequate access to nutrition or health care. In the four developing countries, this involved selecting children from extremely well-to-do backgrounds to ensure that they were not in any way hampered in their growth potential. For example, in the Indian case, the sample consisted of children whose mothers and fathers each had an average of 17 (!) years of education (WHO 2006b).

As it differs from the previous standard, the new reference standard will lead to changes in levels of undernutrition in all developing countries. ${ }^{33}$ But as it continues to be a single international reference standard, it will not have any significant impact on the observed inter-regional patterns of undernutrition, particularly the inexplicably high rates of undernutrition in South Asia and, to a lesser extent, East Asia.

\footnotetext{
${ }^{29}$ Bogin (1988) assumes a short-fall of some $2.5 \mathrm{~cm}$ based on an assessment of Pakistani children in England. Despite considerable catch-up in terminal height in recent decades (which appears to have subsided since), Japanese children are still believed to be some 3-6 cm shorter than US children (Bogin, 1988). Martorell et al. (1988) suggests that Asian children, including South and East Asians, are some $3.5 \mathrm{~cm}$ shorter by age 7 .

${ }^{30}$ In fact, there is some evidence suggesting that African children grow faster (e.g. Martorell, 1988, MacFarlane, 1995) than US children; others suggest that the variability of growth and weight gain in Africa is much larger than elsewhere, related to the higher genetic diversity of Africa's populations, which in turn is consistent with humanity's origin in Africa (Kidd et al. 1996). This would make a single standard from the USA not suitable to assess undernutrition in the genetically more diverse African context.

${ }^{31}$ The reason for this surprising sensitivity of the undernutrition rates to small changes in the reference standard is related to the fact that in a country with high undernutrition rates, the mode of the Z-score distribution is close to the cut-off of -2 .

32 The main reasons for this decision were related to problems related to the splicing of the two reference populations at age 2 and the fact that mothers who followed the WHO recommendation of six months of exclusive breast-feeding found that their children were falling behind in growth and weight gain when compared to the bottle-fed children that made up the reference standard. See WHO $(1995,1999)$ and de Onis and Habicht (1996) for a discussion.

${ }^{33}$ Initial application of the new standard to some DHS surveys suggests that stunting and wasting rates increase, while underweight rates decline. See also WHO (2006a).
} 
At the same time, the data used to create this new standard sheds an interesting light on possible inter-population differences in child growth. Even though the selection procedure of enrolling children was such that it would minimize and possibly bias downward inter-population differences, ${ }^{34}$ it nevertheless remains the case that small differences between the countries considered are found. As shown in WHO (2006c), mean lengths in India and in Oman are between $0.5-2 \%$ smaller than in the pooled sample at different ages, and the differences are about twice as large compared to children in Norway and Brazil, the tallest group in the sample. Particularly noteworthy is also that 5 year old children in India were about $2 \%$ shorter than in Ghana.

Unfortunately, WHO does not make available similar data for weight by age in the six countries. But from Bandhari et al. (2002) which assess the Indian sample of children, one can deduce that the children in the sample had an average Z-score of -0.45 compared to the old reference standard. This would be roughly equivalent to a $3.5 \%$ lower weight for age of these children compared to the new standard.

Both pieces of evidence suggest that the consensus in the literature of about 1-3\% lower growth potential of South Asian children compared to children in the US, Europe, or Africa continues to hold. Applying one reference standard would therefore, in a comparative sense, overestimate undernutrition in South Asia by between 8-20 percentage points.

Another way to empirically investigate the plausibility of this measurement issue is to see whether ways to 'correct' underweight rates would change our assessment of the impact of underweight on under five mortality. In Table 7 we found that underweight rates do not significantly affect under five mortality in the panel regressions (see column 5). ${ }^{35}$ In order to 'correct' underweight rates by these apparently slight genetic differentials in growth potential between regions, we use the random effects panel model (column 6 in Table 6) to predict underweight rates omitting the country random effects. $^{36}$ I then plug these predicted underweight rates in our under five mortality regressions in Table 7 (see column and 6 with 'underweighthat'). The predicted underweight rates now have a strong and significant impact on under five mortality rates in the expected direction. While this does not prove that measurement issues are the main reason for the inexplicably high comparable rates of childhood undernutrition in South Asia, they are fully consistent with that view and then show the plausible result that properly measured undernutrition rates do have a significant impact on under five mortality. This view also is more plausible than the alternative explanation for the insignificant effect of underweight rates on child mortality, which is that underweight is not a significant risk factor for mortality (favored by the 'small but healthy' school).

Thus our assessment of the undernourishment and undernutrition data is that the former is conceptually flawed and based on very weak data while the latter might be affected by problems related to small genetic differences in growth potential between populations which might account for the comparatively high rates of undernutrition in South and East Asia.

\footnotetext{
${ }^{34}$ Two factors might play a role here. To the extent that genetically taller and heavier people are over-represented among the well-to-do of a developing country, choosing a sample of well-to-do might not provide an unbiased sample of the genetic potential of a population. See Klasen and Moradi (2000) for a discussion. Second, children with morbidity or very low growth were dropped from the sample or not considered in the construction of the standard which might influence the results. See WHO (2006a)

35 The same was also true in the cross-section regressions (not shown).

${ }^{36} \mathrm{We}$ are thus effectively using the undernourishment rate using in the regression in Table 6 as an instrument. As we are omitting the random effects when doing the predictions, it is however, not a usual two-stage least squares estimation. Doing such a estimation does not generate a significant coefficient for the underweight variable. This confirms our suggestion that the problem is not generalized measurement error of the underweight variable but the measurement error with a systematic regional pattern.
} 
I should point out that this way I can only account for the unusually high rates of underntrition in Asia, but not the unusually high rates of under-five mortality in Sub Saharan Africa. But since the regional dummies for Sub Saharan Africa were much lower to begin with and much of the total inter-regional difference could be explained, it is likely that omitted variables or specification issues might account for the remaining unexplained portion of under five mortality there. Among the issues to consider are the effects of health care access and quality for which there are no good internationally comparable data, the role of non-linearities and interactions, and the potential effects of compounding. As suggested in Klasen (2000b), it might be the case that high fertility is leading to higher under five mortality in Africa than elsewhere, or that the interaction between risk factors is multiplicative rather than additive (see also Pelletier, 1994). But clearly these are issues that need further investigation. Given the poor progress in child mortality reductions in Africa, understanding the drivers of the poor performance there should be a high priority.

\section{Research and Policy Implications of the Inter-Regional Puzzles}

In this paper, I discussed inter-regional puzzles in indicators of income poverty, undernourishment, childhood undernutrition, and child mortality. I suggested that the undernourishment and childhood undernutrition indicators exhibit the most peculiar inter-regional patterns and speculated about the causes of these patterns, particularly emphasizing data and measurement issues. This leads to a number of important questions for research and policy.

Let me first turn to the problems with the undernourishment indicator. In principle, some of the empirical problems with this indicator, particularly the poor data on production and

autoconsumption of food, could be improved. But the question remains whether the conceptual problems and implicit assumptions made are so problematic that it is impossible to come up with a reliable aggregate measure of 'hunger'. Given the discussion above, I would submit that it seems indeed impossible to develop a reliable measure of 'hunger' using such an aggregate input-oriented approach for several reasons. First, it is not very clear whether average caloric deficiency over a three year period is really a good measure of 'hunger'. It ignores inter-seasonal variations, shortterm shocks, and the role of other nutrients. Second, we know simply too little about critical assumptions of this approach, including how many calories get wasted, how calories are distributed among the population in different countries (which is likely to be different across space and changes over time), and what the caloric requirements are for different population groups, depending on their circumstances. I find it also implausible that we will reliably fill these knowledge gaps anytime soon, certainly not before 2015. So frankly my (probably contentious) conclusion is that further research in this area is unlikely to generate a reliable and comparable aggregate indicator of 'hunger' so that it is probably better to think about alternative approaches.

What are plausible alternatives to generating indicators of 'hunger' or caloric deficiency? One plausible alternative would be to use household expenditure surveys to assess caloric deficiency as proposed, for example, by Smith (2003). Using the expenditure pattern of households, one could determine which households have insufficient effective access to calories by examining the caloric content of their food expenditures (plus their autoconsumption). In fact, precisely this approach is already used to derive 'food poverty' measures in many countries following suggestions by Ravallion (1994). Using these surveys one could then derive national and global figures of caloric deficiency. One could also identify particular vulnerable groups, study the determinants of caloric deficiency, and target interventions. So it would not suffer from some of the short-comings of the current undernourishment measure.

While this might be a promising approach that clearly deserves further research, some cautionary remarks are in order. First, some of the problems with the undernourishment measure still exist. In particular, food expenditure does not equal food intake (as food is wasted/lost at the household 
level) and they are not very closely correlated in some survey evidence (e.g. Lence, 2003). Also, calories are not everything that is needed to be adequately nourished. Moreover, this approach does not solve the cut-off issue and still needs to make (potentially dubious) assumptions about caloric needs for different people.

Second, there are serious data reliability and comparability issues using household expenditure surveys. Reported food expenditures are sensitive to the recall period and the number of food items considered, they tend to be generally underreported, and questionnaires are infrequent and not standardized across countries and across time. ${ }^{37}$ Third, there is also a difficult conceptual issue to consider. It is empirically the case that many households who would be classified as 'hungry' (because they purchase too few calories) could easily escape this hunger by switching to calories that are cheaper. ${ }^{38}$ Often such switches would have no negative and possibly even positive nutritional implications (e.g. if households switched from higher cost/calorie sugar, coffee, tea, sweets, fats to much cheaper grain). Given the vast differences in costs per calories, the required switch would be rather small for most households. How to assess this partly preference-driven caloric deficiency in an assessment of 'hunger' is a difficult issue. ${ }^{39}$ Nevertheless, this approach to estimating calorie deficiency and hunger is well worth exploring further as it appears, to me at least, that some of the existing empirical and conceptual problems could potentially be addressed.

A second alternative would, of course, be to jettison the attempt to produce a figure on the number of 'hungry' people altogether. Apart from the media interest the yearly publication of the number of 'hungry' people generates, the meaning, interpretation, and policy implications of levels and trends in the number of 'hungry' people are so unclear that it serves no useful policy purpose. Instead, it might be much more valuable to concentrate on identifying incidences of acute food shortages, i.e. famines, as it is in those instances that the life, health, and welfare of affected populations are severely threatened. As suggested in Sen's 'entitlement approach' to analyzing famines (Sen, 1984, Drèze and Sen, 1989), monitoring food availability is a poor predictor of such instances of acute food shortage. Instead, a focus on entitlements of affected populations is critical, which might be monitored by examining food prices, wages, unemployment rates, and other indicators of entitlement (including food production as a source of entitlement for those producing it). While many countries have quite successfully been able to identify famine threats and address them (Drèze and Sen, 1989), the research challenge would be to examine how such instances of severe food shortage can reliably be detected in countries with weak institutions, lack of democracy, absent or controlled media, or states that have failed or are in civil conflict. Improving data and measurement in this area of acute 'hunger' appears to be a promising and policy-relevant way forward.

Turning to the childhood undernutrition indicator, the research implications of the inter-regional puzzles in this indicator are, in some sense, less dramatic and more straight-forward. There is little doubt that the general approach to measuring childhood undernutrition using anthropometric indicators has much merit, both at the level of the individual child as well as at the level of populations. The main critical research issue is to further investigate whether indeed the (slight) genetic differences in growth potential of children are the most important reason for the unusually high rates of undernutrition in South Asia and, to a lesser extent, East Asia. This paper has presented some evidence in favor of this view but clearly this is far from settled. A second possible explanation of these unusually high South Asian rates of childhood undernutrition may be related to delayed impacts of past undernutrition on undernutrition rates today. This could possibly also explain that South Asian children growing up in a wealthy and healthy environment still are growing and gaining weight at lower rates than children elsewhere leading to this $1-3 \%$ difference

\footnotetext{
${ }^{37}$ See discussion by Smith (2003) and FAO (2003) more generally.

${ }^{38}$ Increasing the food share would also be possible, but this would cut into non-food necessities.

${ }^{39}$ For a discussion, see Deaton (1997).
} 
observed above. This, in turn, could happen if the small stature of the mother (a result of her undernutrition in the past) affected the stature of her children even though during pregnancy, infancy and childhood adequate nutrition was available for both mother and child. ${ }^{40}$

Three areas of research might be able to sort out these issues. First, carefully examining the longterm anthropometric performance of immigrant children in rich countries will give some guidance on the relevance of genetic differences for child growth. Existing studies are often constrained by relatively small samples, selectivity problems of immigrants, and too short a time frame for an assessment, but these issues become less important as immigration is increasing and we have longer time frames of data to study the effects. ${ }^{41}$ Second, examining cohort trends of well-to-do populations might shed light on the relative importance of the two competing hypotheses. If wellto-do South Asians show evidence of rapid secular growth and weight gain by cohort (that is exceeding the secular growth observed in rich countries) so that the gap between them and richer countries and other regions is vanishing, this would be evidence favoring the delayed impact of past undernutrition as a cause of South Asia's high rates of childhood undernutrition. ${ }^{42}$ Third, possibly direct genetic evidence might shed light on this issue. ${ }^{43}$ Depending on the outcome of these three research areas, the question whether a single reference standard is useful for international comparisons and global accounting of childhood undernutrition can be answered.

As far as the unusually high rates of child mortality in Sub Saharan Africa are concerned, they clearly should be the focus on much closer investigation. As suggested above, there are a number of potential explanations including non-linearities, interaction and compounding effects which should be investigated using micro and cross-country evidence.

At the policy level, some issues also arise. First, resolving the question about the relative severity of childhood undernutrition in different regions clearly is of some relevance. While it is undoubtedly the case that childhood undernutrition is a very serious issue in South Asia (and might be systematically underestimated using the cut-off for the Z-score of -2), Sub Saharan Africa should attract equal attention if it is the case that much of the difference in rates between the two regions is driven by measurement error. Second, it appears that the link between childhood undernutrition and child mortality is not as close as sometimes suggested. ${ }^{44}$ This would imply that one cannot hope that improvement in one indicator will necessarily lead to improvements in the other so that one might need policies that address each of the two issues separately. Particularly, the very high rates of child mortality in Sub Saharan Africa deserve much closer attention of policy-makers. Lastly, before agreeing to the MDGs and 'dividing up' the targets and indicators among UN institutions and the World Bank, it would have been well worth examining their reliability and comparability, as well as the conceptual and empirical linkages between them. As suggested above, some of them might need a re-think.

\section{References}

\footnotetext{
${ }^{40}$ In support of such a theory one can point out that the mothers from India and Oman included in the new WHO reference standard were about $4 \mathrm{~cm}$ shorter than the mothers in the other sites, despite their very high socio-economic status thus suggesting that they might have experienced nutritional difficulties as children (see WHO 2006b). But this could affect their off-spring only if a currently well-nourished but short mother (based on nutritional problems in the past) creates growth and weight problems for her off-spring that are unrelated to genetic influences (for example, by having a smaller pelvis leading to smaller children who do not fully catch up after birth). For a discussion, see Mohamed et al (2004), and Osmani and Sen (2002).

${ }^{41}$ See, for example, Bogin (1988) and Eveleth and Tanner (1990).

${ }^{42}$ Evidence from Japan suggests that rapid rates of catch-up are possible but, to date, a sizable gap has remained between the height of Japanese and other rich country adults and children (Mosk, 1996).

${ }^{43}$ See Kidd et al. (1996) for some intriguing evidence in this regard.

${ }^{44}$ See also Harttgen and Misselhorn (2006) for further evidence in this regard.
} 
Adams, R. (2004) Economic Growth, Inequality and Poverty: Estimating the Growth Elasticity of Poverty. World Development 32(12). pp 1989-2014.

Anand, S. and M. Ravallion. (1993). Human Development in Poor Countries: On the Role of Private Incomes and Public Services. Journal of Economic Perspectives 7: 133-150.

Anand and Bärninghausen (2004). Human resource and health outcomes: cross-country econometric study. The Lancet 364: 1603-09.

Bhandari, N. R. Bahl, S. Taneja, M de Onis, M. Bhan. Growth Performance of affluent Indian children is similar to that in developed countries. Bulletin of the World Health Organization 80(3) 189-195.

Bogin, B. (1988). Patterns of Human Growth. Cambridge: Cambridge University Press.

Bourguignon, F. (2003) The Growth Elasticity of Poverty Reduction: Explaining Heterogeneity across Countries and Time Periods. In T. Eichler and S. Turnovsky (eds.). Growth and Inequality. Cambridge. MIT Press.

Brinkmann, H. J. Drukker, and B. Slot (1997). GDP per Capita and the Biological Standard of Living in Contemporary Developing Countries, in Baten, J. and J. Komlos (eds.): The Biological Standard of Living. Berlin: Springer.

Datt, G. and M. Ravallion. (1992). Growth and Redistribution Components of Changes in Poverty Measures: A Decomposition with Application to Brazil and India in the 1980s. Journal of Development Economics 38(2). pp. 275-295.

Davies, D.P. (1988). The Importance of Genetic Influences on Growth in Early Childhood with Particular Reference to Children of Asiatic Origin, in: Waterlow, J (Hrsg.): Linear Growth Retardation in Developing Countries, New York: Raven Press.

Devarajan, S. (2002). Goals for Development. Policy Research Working Paper No. 2819. Washington DC: The World Bank.

Drèze, J. and A. Sen (1989) Hunger and Public Action. New York: Oxford University Press.

Eveleth, P. and J. Tanner (1990). Worldwide Variation in Human Growth. Cambridge: Cambridge University Press.

FAO (ed.) Measurement and Assessment of Food Deprivation and Undernutrition. Rome: FAO.

Gallup, J. and J. Sachs (2001) The Economic Burden of Malaria. American Journal of Tropiocalö Medicine and Hygiene 64 (1,2)S: 85-96.

Graitcer, P. and E. Gentry. 1981. Measuring Children: One Reference for All. The Lancet August 8, 1981: 297-299.

Gorstein, J. et al. (1994). Issues in the Assessment of Nutritional Status Using Anthropometry. Bulletin of the World Health Organization 72:273-283.

Guilkey, D. und R. Riphahn (1998). The determinants of child mortality in the Philippines: Estimation of a Structural Model, Journal of Development Economics 56: 281-305. 
Habicht, JP, et al. (1974). Height and Weight in Pre-School Children: How Relevant are Ethnic Differences in Growth Potential? The Lancet April 6, 1974: 611-614.

Harttgen, K. and M. Misselhorn (2006). A Mulitlevel Approach to Explain Child Mortality and Undernutrition in South Asia and Sub-Saharan Africa. Mimeographed, University of Göttingen.

Kidd, KK, et al. (1996). Minisatellite Diversity Supports a Recent African Origin for Modern Humans. Natural Genetics 13: 154-60.

Klasen, S. and M. Misselhorn (2006). Determinants of the Growth Semielasticity of Poverty Reduction. Mimeographed, University of Göttingen.

Klasen, S. (2000a) Measuring Poverty and Deprivation in South Africa. Review of Income and Wealth 46:33-58

Klasen, S. (2000b) Malnourished and Surviving in South Asia, better nourished and Dying Young in Africa: What can explain this puzzle? SFB Working Paper No. 214, Munich, Department of Statistics.

Klasen, S (2003) Malnourished and Surviving in South Asia, better nourished and Dying Young in Africa: What can explain this puzzle? In FAO (ed.) Measurement and Assessment of Food Deprivation and Undernutrition. Rome: FAO, pp. 283-287.

Klasen, S. and A. Moradi (2000). “The Nutritional Status of Elites in India, Kenya, and Zambia: An appropriate guide for developing reference standards for undernutrition?” SFB Discussion Paper No. 217, Munich: Department of Statistics.

Lancet (1984). A Measure of Agreement on Growth Standards. The Lancet January 21, 1984: Editorial.

Lence, S. (2003) Household expenditure survey methods. In FAO (ed.) Measurement and Assessment of Food Deprivation and Undernutrition. Rome: FAO, pp. 91-96

Lipton, M. and M. Ravallion. 1995. Poverty and Policy. In: Behrman, J. and T.N. Srinivasan (eds.) Handbook of Development Economics Vol 3b. Amsterdam: North Holland.

Martorell, R., F. Mendoza, and R. Castillo (1988). Poverty and Stature in Children. Waterlow, J (Hrsg.): Linear Growth Retardation in Developing Countries, New York: Raven Press.

McGillivray, M. (2005). Measuring Non-Economic Well-Being Achievement. Review of Income and Wealth 51(2) 337-365.

MacFarlane, SB. (1995). A Universal Growth Reference of Fool's Gold? European Journal of Clinical Nutrition 49: 745-753.

Mohamed, AJ, Onyango, AW, de Onis, M, Prakash, N, Mabry RM, and DH Alasfoor. (2004) Socioeconomic predictors of unconstrained child growth in Muscat, Oman. Eastern Mediterranean Health Journal 10:295-302.

Mosk, C. 1996. Making Health Work: Human Growth in Modern Japan. Berkeley, CA: University of California Press.

Mosley, W. and L. Chen. 1984. An Analytical Framework for the Study of Child Survival in Developing Countries. In: Mosley, W. (ed.) Child Survival: Strategies for Research. New York: Population Council.

Naiken, L. (2003) FAO methodology for estimating the prevalence of food deprivation and undernutrition. In: FAO (ed.) Measurement and Assessment of Food Deprivation and Undernutrition. Rome: FAO, pp. 7-42.

Nussbaum, M. and A. Sen. 1993. The Quality of Life. New York: Oxford University Press. 
de Onis, M. and JP Habicht (1996). Anthropometric Reference Data for International Use: Recommendations from a World Health Organization Expert Committee. American Journal of Clinical Nutrition 64: 650-8.

De Onis, M. and S. Garza. (2006). Foreword. Acta Pediatrica Supplement 450: 5-6.

Osmani, S. R. (1997) Poverty and Nutrition in South Asia, in UN Sub-Committee on Nutrition (eds.): Nutrition and Poverty. Geneva: WHO.

----- (1990) Nutrition and the Economics of Food: Implications of Some Recent Controversies. In Dreze, J. and A. Sen (eds): The Political Economy of Hunger, Vol. 1. New York: Oxford University Press.

Osmani, S. and A. Sen. The hidden penalties of gender inequality: fetal origins of ill-health

Economics and Human Biology, 2003, vol. 1, issue 1, pages 105-121

Pelletier, D. (1998). Malnutrition, Morbidity, and Child Mortality in Developing Countries, in United Nations (eds.): Too young to die: Genes or Gender? New York: United Nations.

----- . (1994). The relationship between child anthropometry and mortality in developing countries. Journal of Nutrition Supplement 124: 2047S-2081S.

-----, E. Frongillo and J-P Habicht (1993): Epidemiological Evidence for a potentiaing effect of malnutrition on child mortality. American Journal of Public Health 83: 1130-33.

Pritchett, L. and L. Summers (1996). Wealthier is Healthier. Journal of Human Resources 31: 841868.

Ravallion, M. (1994) Poverty Comparisons. Chur: Harwood Academic Publishers.

Ramalingaswami, V. , U. Jonsson, and J. Rohde (1996). The South Asian Enigma, in UNICEF: The Progress of Nations. New York: UNICEF.

Seckler, D. (1982). Small but Healthy: A Basic Hypothesis in the Theory, Measurement and Policy of Malnutrition, in: Sukhatme, D. (Hrsg.): Newer Concepts in Nutrition and their Implication for Policy (Pune: Maharashtra Association for the Cultivation of Science).

Sen, A. (1998). Development as Freedom. New York: Knopf.

Sen, A. (1988) The Concept of Development. In Chenery, H. and T.N. Srinivasan (eds.) Handbook of Development Economics. Amsterdam: North-Holland.

Sen, A. (1984) Poverty and Famines. Oxford: Oxford University Press.

Smith. L. and L. Haddadd (1999). Explaining Child Malnutrition in Developing Countries: A Cross-Country Analysis. IFPRI Discussion Paper No. 60. Washington DC: IFPRI.

Smith, L. and L. Haddad (2002). How potent is economic growth in reducing undernutrition? What are the pathways of impact? New cross-country evidence. Economic Development and Cultural Change 51: 55-76.

Smith, L., U. Ramakrishnan, L. Haddad, R. Martorell, and A. Ndyae. (2003). The Importance of Women's Status for Child Nutrition in Developing Countries. IFPRI Research Report No. 131. Washington DC: IFPRI.

Smith, L. (2003) The use of household expenditure surveys for the assessment of food insecurity. In FAO (ed.) Measurement and Assessment of Food Deprivation and Undernutrition. Rome: FAO, pp. 57-88.

Sukhatme, D. (1982). Measurement of Undernutrition. Economic and Political Weekly 17.

Svedberg, P. (1991). Poverty and Undernutrition in Sub-Saharan Africa. Stockholm: Swedish Institute for International Economics. 
Svedberg, P. (1999) "841 Million Undernourished?", World Development 28.

-------. (2002) Undernutrition overestimated. Economic Development and Cultural Change 51(1):536

UNDP. 1990, 2000. Human Development Report. New York: Oxford University Press.

UNICEF (1998). The State of World's Children: Focus on Nutrition. New York: UNICEF.

WHO (1983). Measuring Change in Nutritional Status. Geneva: WHO.

WHO (1995) Physical Status: The Use and Interpretation of Anthropometry. WHO Technical Report Series No. 854. Geneva: WHO.

WHO (1999) Infant and young child nutrition: the WHO multicentre growth reference study. WHO Implementations and Resolutions EB105/inf.doc./I. Geneva: WHO.

WHO Multicentre growth reference study group (2006a) WHO Child Growth Standards based on length/height, weight, and age. Acta Paediatrica Suppl. 450: 76-85.

WHO Multicentre growth reference study group (2006b). Enrolment and baseline characteristics in the WHO multicentre growth reference study. Acta Paediatrica Suppl. 450: 5-15.

WHO Multicentre growth reference study group (2006c). Assessment of differences in linear growth among populations in the WHO Multicentre Growth Reference Study. Acta Paediatrica Suppl. 450: 56-65.

World Bank (2005) World Development Indicators. Washington DC: The World Bank.

World Bank (2000). World Development Report 2000/01: Attacking Poverty. New York: Oxford University Press.

World Bank (1997). Confronting AIDS. Washington DC: The World Bank.

World Bank (1993) World Development Report 1993: Investing in Health. New York: Oxford University Press.

Table 1: The poverty, nutrition, and mortality related MDGs, Targets and Indicators

\begin{tabular}{|c|c|c|c|}
\hline Goal & Target & Indicator & $\begin{array}{l}\text { Official Data } \\
\text { Source }\end{array}$ \\
\hline \multirow[t]{3}{*}{$\begin{array}{l}\text { 1. Eradicate Extreme } \\
\text { Poverty and hunger }\end{array}$} & $\begin{array}{l}\text { 1. Halve (between } \\
1990 \text { and 2015) the } \\
\text { share of the } \\
\text { population living on } \\
\text { less than } \$ 1 \text { a day }\end{array}$ & $\begin{array}{l}\text { 1. Proportion of } \\
\text { population below } \$ 1 \\
\text { (1993PPP) }\end{array}$ & World Bank \\
\hline & \multirow{2}{*}{$\begin{array}{l}\text { 2. Halve (between } \\
1990 \text { and 2015) the } \\
\text { proportion of people } \\
\text { who suffer from } \\
\text { hunger }\end{array}$} & $\begin{array}{l}\text { 2. Prevalence of } \\
\text { underweight children } \\
\text { under } 5 \text { years of age }\end{array}$ & UNICEF-WHO \\
\hline & & $\begin{array}{l}\text { 3. Proportion of } \\
\text { population below } \\
\text { minimum level of } \\
\text { dietary energy } \\
\text { consumption }\end{array}$ & FAO \\
\hline $\begin{array}{l}\text { 4. Reduce Child } \\
\text { Mortality }\end{array}$ & 1. Reduce by two- & $\begin{array}{l}\text { 1. Under-five } \\
\text { Mortality Rate }\end{array}$ & UNICEF-WHO \\
\hline
\end{tabular}




\begin{tabular}{|l|l|l|l|}
\hline & $\begin{array}{l}\text { thirds (between 1990 } \\
\text { and 2015) the under- } \\
\text { five mortality rate }\end{array}$ & $\begin{array}{l}\text { 2. Infant Mortality } \\
\text { Rate }\end{array}$ & UNICEF-WHO \\
\hline
\end{tabular}


Table 2: Pairwise Correlation Coefficients for 2000

\begin{tabular}{|c|c|c|c|c|c|c|c|c|c|c|}
\hline & $\begin{array}{c}\$ 1 \text { a day } \\
\text { head- } \\
\text { count }\end{array}$ & $\begin{array}{l}\$ 2 \text { a day } \\
\text { Headcount }\end{array}$ & $\begin{array}{c}\text { Share } \\
\text { under- } \\
\text { nourished }\end{array}$ & $\begin{array}{l}\text { Under } 5 \\
\text { Mortality }\end{array}$ & $\begin{array}{c}\text { Infant } \\
\text { Mortality }\end{array}$ & $\begin{array}{c}\text { Share } \\
\text { Wasted }\end{array}$ & $\begin{array}{l}\text { Share } \\
\text { Stunted }\end{array}$ & $\begin{array}{c}\text { Share } \\
\text { Under- } \\
\text { weight }\end{array}$ & $\begin{array}{l}\text { Female } \\
\text { Literacy }\end{array}$ & $\begin{array}{c}\text { Log } \\
\text { (GDP/cap) }\end{array}$ \\
\hline $\begin{array}{l}\text { \$1 a day head- } \\
\text { count }\end{array}$ & 1.0000 & & & & & & & & & \\
\hline $\begin{array}{l}\text { \$2 a day } \\
\text { Headcount }\end{array}$ & $0.8836^{* *}$ & 1.0000 & & & & & & & & \\
\hline $\begin{array}{c}\text { Share under- } \\
\text { nourished }\end{array}$ & $0.6034^{* *}$ & $0.6509^{* *}$ & 1.0000 & & & & & & & \\
\hline $\begin{array}{c}\text { Under } 5 \\
\text { Mortality }\end{array}$ & $0.7426^{* *}$ & $0.7363^{* *}$ & $0.6388^{* *}$ & 1.0000 & & & & & & \\
\hline Infant Mortality & $0.6828^{* *}$ & $0.7083^{* *}$ & $0.6535^{* *}$ & $0.9843^{* *}$ & 1.0000 & & & & & \\
\hline Share Wasted & $0.2483^{*}$ & $0.4347^{* *}$ & $0.2688^{*}$ & $0.4354^{* *}$ & $0.4326^{* *}$ & 1.0000 & & & & \\
\hline Share Stunted & $0.6432^{* *}$ & $0.7785^{* *}$ & $0.6060^{* *}$ & $0.6780^{* *}$ & $0.6915^{* *}$ & $0.4183^{* *}$ & 1.0000 & & & \\
\hline $\begin{array}{l}\text { Share Under- } \\
\text { weight }\end{array}$ & $0.5151^{* *}$ & $0.6875^{* *}$ & $0.5504^{* *}$ & $0.6062^{* *}$ & $0.6098^{* *}$ & $0.7287^{* *}$ & $0.8470^{* *}$ & 1.0000 & & \\
\hline Female Literacy & $-0.4834^{* *}$ & $-0.5710^{* *}$ & $-0.3933^{* *}$ & $-0.7267^{* *}$ & $-0.7158^{* *}$ & $-0.5484^{* *}$ & $-0.6068^{* *}$ & $-0.6753^{* *}$ & 1.0000 & \\
\hline Log (GDP/cap) & $-0.6855^{* *}$ & $-0.7941^{* *}$ & $-0.7110^{* *}$ & $-0.8034^{* *}$ & $-0.7983^{* *}$ & $-0.4465^{* *}$ & $-0.7880^{* *}$ & $-0.7109^{* *}$ & $0.6307^{* *}$ & 1.0000 \\
\hline
\end{tabular}

Note. The figures refer to pairwise (Pearson) corerlation coefficients between the various indicators. The number of observations upon which they are based varies from 66 to 117 country observations. Significance levels: ** 99 Percent. * 95 Percent \#90 percent. 
Table 3: Pairwise Correlation Coefficients of First Differences of Variables (2000-1990)

\begin{tabular}{|c|c|c|c|c|c|c|c|c|c|c|}
\hline & $\begin{array}{l}\text { \$1 a day } \\
\text { head- } \\
\text { count }\end{array}$ & $\begin{array}{l}\$ 2 \text { a day } \\
\text { Headcount }\end{array}$ & $\begin{array}{c}\text { Share } \\
\text { under- } \\
\text { nourished }\end{array}$ & $\begin{array}{l}\text { Under } 5 \\
\text { Mortality }\end{array}$ & $\begin{array}{c}\text { Infant } \\
\text { Mortality }\end{array}$ & $\begin{array}{c}\text { Share } \\
\text { Wasted }\end{array}$ & $\begin{array}{c}\text { Share } \\
\text { Stunted }\end{array}$ & $\begin{array}{l}\text { Share } \\
\text { Under- } \\
\text { weight }\end{array}$ & $\begin{array}{l}\text { Female } \\
\text { Literacy }\end{array}$ & $\begin{array}{c}\text { Log } \\
\text { (GDP/cap) }\end{array}$ \\
\hline $\begin{array}{l}\$ 1 \text { a day head- } \\
\text { count }\end{array}$ & 1.0000 & & & & & & & & & \\
\hline $\begin{array}{c}\text { \$2 a day } \\
\text { Headcount }\end{array}$ & $0.7465^{* *}$ & 1.0000 & & & & & & & & \\
\hline $\begin{array}{l}\text { Share under- } \\
\text { nourished }\end{array}$ & -0.0070 & -0.0057 & 1.0000 & & & & & & & \\
\hline $\begin{array}{c}\text { Under } 5 \\
\text { Mortality }\end{array}$ & 0.0444 & 0.0621 & 0.2255 & 1.0000 & & & & & & \\
\hline Infant Mortality & 0.0665 & 0.0924 & 0.2142 & $0.9618^{* *}$ & 1.0000 & & & & & \\
\hline Share Wasted & -0.1602 & -0.1686 & 0.1481 & 0.0775 & 0.0677 & 1.0000 & & & & \\
\hline Share Stunted & $0.3178^{* *}$ & 0.2336 & $0.2234^{\#}$ & $0.1971^{\#}$ & $0.2062^{\#}$ & 0.0282 & 1.0000 & & & \\
\hline $\begin{array}{l}\text { Share Under- } \\
\text { weight }\end{array}$ & 0.1645 & 0.1733 & $0.3127^{* *}$ & $0.2462^{*}$ & $0.2149^{*}$ & $0.4721^{* *}$ & $0.6682^{* *}$ & 1.0000 & & \\
\hline Female Literacy & -0.0041 & -0.1783 & -0.0585 & -0.0261 & -0.0170 & 0.1033 & -0.0466 & 0.0525 & 1.0000 & \\
\hline Log (GDP/cap) & $-0.111^{* *}$ & $-0.6359^{* *}$ & $-0.2807^{*}$ & $-0.2296^{*}$ & $-0.2515^{*}$ & -0.0614 & $-0.1946^{\#}$ & -0.1724 & $0.2032^{\#}$ & 1.0000 \\
\hline
\end{tabular}

Note. The figures refer to pairwise (Pearson) correlation coefficients between the various indicators. The observations upon which they are based varies from 64 to 117 country observations. Significance levels: ** 99 Percent. * 95 Percent \#90 percent. 
Table 4 : Poverty, Undernourishment, Childhood Undernutrition, and Child Mortality by Region

\begin{tabular}{|c|c|c|c|c|c|c|}
\hline & $\begin{array}{l}\text { Sub Saharan } \\
\text { Africa }\end{array}$ & $\begin{array}{l}\text { South } \\
\text { Asia }\end{array}$ & $\begin{array}{l}\text { East Asia } \\
\text { and Pacific }\end{array}$ & $\begin{array}{l}\text { Middle East \& } \\
\text { North Africa }\end{array}$ & Latin America & Caribbean \\
\hline \multicolumn{7}{|l|}{1990} \\
\hline Per Capita GDP (PPP) & 1022 & 1512 & 1759 & 3449 & 5571 & 3298 \\
\hline $1 \$$ a day headcount & 49.2 & 41.3 & 26.5 & 2.4 & 12.6 & 5.4 \\
\hline $2 \$$ a day headcount & 78.4 & 85.5 & 69.6 & 21.9 & 30.8 & 21.7 \\
\hline $\begin{array}{l}\text { Undernourishment } \\
\text { Rate }\end{array}$ & 30.0 & 25.8 & 19.7 & 6.5 & 13.1 & 37.8 \\
\hline Share Stunted & 39.3 & 52.6 & 33.8 & 25.0 & 19.4 & 20.8 \\
\hline Share Wasted & 7.3 & 16.2 & 5.0 & 5.2 & 2.7 & 3.2 \\
\hline Share Underweight & 29.3 & 52.9 & 21.8 & 12.9 & 9.7 & 15.6 \\
\hline Under 5 mortality rate & 189 & 125 & 55 & 88 & 53 & 88 \\
\hline Infant Mortality Rate & 107 & 86 & 41 & 63 & 43 & 64 \\
\hline \multicolumn{7}{|l|}{2000} \\
\hline Per Capita GDP (PPP) & 977 & 2089 & 3444 & 4397 & 6353 & 3882 \\
\hline $1 \$$ a day headcount & 49.7 & 31.9 & 14.4 & 2.1 & 10.8 & 0.3 \\
\hline $2 \$$ a day headcount & 80.0 & 77.8 & 46.6 & 21.3 & 26.8 & 4.1 \\
\hline $\begin{array}{l}\text { Undernourishment } \\
\text { Rate }\end{array}$ & 27.9 & 21.7 & 16.2 & 6.0 & 10.4 & 30.1 \\
\hline Share Stunted & 40.5 & 43.7 & 16.6 & 19.1 & 15.3 & 12.2 \\
\hline Share Wasted & 7.8 & 14.8 & 3.0 & 4.3 & 1.9 & 3.4 \\
\hline Share Underweight & 29.0 & 45.4 & 13.8 & 10.2 & 7.1 & 9.7 \\
\hline Under 5 mortality rate & 178 & 93 & 41 & 50 & 35 & 73 \\
\hline Infant Mortality Rate & 103 & 67 & 32 & 42 & 30 & 53 \\
\hline
\end{tabular}

Note: Worst performing region in a particular indicator is highlighted in bold. These are population-weighted averages and the samples are nearly (but not entirely) identical across indicators and over the two time periods. To minimize differences in the samples between indicators, only observations were included where poverty headcounts and undernourishment rates were available as these indicators have the largest data gaps. As there are isolated data gaps in some of the other indicators as well, in Sub Saharan Africa, East Asia, Latin America, and the Caribbean the sample differs very slightly based on the availability of data for each indicator (usually due to the unavailability of the wasting indicator for individual countries with negligible impact on the reported weighted averages). The exception is the Caribbean where the inclusion of Haiti (where the

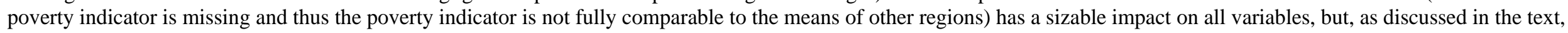
particularly on mean undernourishment rates. Please note that South Africa is not included which would have a major impact on the reported average GDP levels for SubSaharan Africa. As data on undernourishment in Eastern Europe and Central Asia are not available, the region has not been included here. 
Table 5: Determinants of Undernourishment Rates

\begin{tabular}{|c|c|c|c|c|}
\hline Regression & 1 & 2 & 3 & 4 \\
\hline Dependent Variable & $\begin{array}{l}\text { Undernourishment } \\
\text { Rate }\end{array}$ & $\begin{array}{l}\text { Undernourishment } \\
\text { Rate }\end{array}$ & $\begin{array}{l}\text { Change in } \\
\text { Undernourishment } \\
\text { Rate }\end{array}$ & Undernourishment \\
\hline Model Specification & $\begin{array}{l}\text { Cross-Section } \\
2000\end{array}$ & $\begin{array}{l}\text { Cross-Section } \\
2000\end{array}$ & $\begin{array}{l}\text { Cross-Section } \\
(2000-1990)\end{array}$ & $\begin{array}{l}\text { Fixed Effects Panel } \\
(1990,2000)\end{array}$ \\
\hline Constant & $\begin{array}{l}95.37 * * * \\
(5.22)\end{array}$ & $\begin{array}{l}81.5^{* * *} \\
(3.69)\end{array}$ & $\begin{array}{l}6.64 * * \\
(2.30)\end{array}$ & $\begin{array}{l}68.86 \\
(1.90)^{* *}\end{array}$ \\
\hline Log(GDP/capita) & $\begin{array}{l}-11.64^{* * *} \\
(-5.82)\end{array}$ & $\begin{array}{l}-9.63 * * * \\
(-3.70)\end{array}$ & $\begin{array}{l}-8.42^{*} \\
(-1.46)\end{array}$ & $\begin{array}{l}-3.77 \\
(-0.96)\end{array}$ \\
\hline Female Literacy & $\begin{array}{l}0.14 * * \\
(2.26)\end{array}$ & $\begin{array}{l}0.11^{*} \\
(1.33)\end{array}$ & $\begin{array}{l}-0.08 \\
(-0.40)\end{array}$ & $\begin{array}{l}-0.31^{* *} \\
(1.73)\end{array}$ \\
\hline Total Fertility Rate & $\begin{array}{l}1.78^{*} \\
(1.62)\end{array}$ & $\begin{array}{l}2.12^{* *} \\
(1.78)\end{array}$ & $\begin{array}{l}0.87 \\
(0.43)\end{array}$ & $\begin{array}{l}0.48 \\
(0.25)\end{array}$ \\
\hline South Asia & & $\begin{array}{c}1.03 \\
(0.24)\end{array}$ & $\begin{array}{l}0.34 \\
(0.23)\end{array}$ & \\
\hline $\begin{array}{l}\text { East Asia and } \\
\text { Pacific }\end{array}$ & & $\begin{array}{l}-0.11 \\
(-0.03)\end{array}$ & $\begin{array}{l}-1.44 \\
(-0.72)\end{array}$ & \\
\hline Latin America & & $\begin{array}{l}-1.58 \\
(-0.40)\end{array}$ & $\begin{array}{l}-2.05 \\
(-0.90)\end{array}$ & \\
\hline Caribbean & & $\begin{array}{l}7.08 \\
(1.00)\end{array}$ & $\begin{array}{l}-2.69 \\
(-0.99)\end{array}$ & \\
\hline $\begin{array}{l}\text { Middle East and } \\
\text { North Africa }\end{array}$ & & $\begin{array}{l}-7.04^{* *} \\
(-1.78)\end{array}$ & $\begin{array}{l}-0.50 \\
(-0.15)\end{array}$ & \\
\hline $\begin{array}{l}\text { Undernourishment } \\
1990\end{array}$ & & & $\begin{array}{l}-0.29 * * * \\
(-4.13) \\
\end{array}$ & \\
\hline $\mathrm{N}$ & 73 & 73 & 69 & 138 \\
\hline Adjusted $\mathrm{R}^{2}$ & 0.479 & 0.487 & 0.216 & 0.230 \\
\hline
\end{tabular}

The first two regressions are based on a cross-section sample for 2000. In the third regression, the change in undernourishment rates between 1990 and 2000 is regressed on initial levels of undernourishment in 1990 and the change in the (non-dummy) independent variables. The fourth regression is a fixed effects regression using data from 1990 and 2000. A Hausman test suggested fixed over random effects. Heteroscedasticity-adjusted t-statistics are shown in parentheses. *, **, *** refers to $90,95 \%$ and $99 \%$ significance levels, respectively (based on a one-tailed test). Sub Saharan Africa is the omitted region. 
Table 6: Determinants of Rates of Moderate Childhood Underweight (share of children Z-score for weight/age below -2)

\begin{tabular}{|c|c|c|c|c|c|c|c|}
\hline Regression & 1 & 2 & 3 & 4 & 5 & 6 & 7 \\
\hline Dep.Variable & $\begin{array}{l}\text { Under- } \\
\text { Weight }\end{array}$ & $\begin{array}{l}\text { Under- } \\
\text { weight }\end{array}$ & $\begin{array}{l}\text { Under- } \\
\text { weight }\end{array}$ & Underweight & $\begin{array}{l}\text { Change } \\
\text { Underweight }\end{array}$ & Underweight & Underweight \\
\hline Model Specification & $\begin{array}{l}\text { Cross- } \\
\text { Section } \\
(2000) \\
\end{array}$ & $\begin{array}{l}\text { Cross- } \\
\text { Section } \\
(2000) \\
\end{array}$ & $\begin{array}{l}\text { Cross- } \\
\text { Section } \\
(2000) \\
\end{array}$ & $\begin{array}{l}\text { Cross- } \\
\text { Section } \\
(2000)\end{array}$ & $\begin{array}{l}\text { Cross- } \\
\text { Section } \\
(2000-1990)\end{array}$ & $\begin{array}{l}\text { Random } \\
\text { Effects Panel } \\
(1990,2000)\end{array}$ & $\begin{array}{l}\text { Pooled Panel } \\
(1980-2000)\end{array}$ \\
\hline Constant & $\begin{array}{l}84.18 * * * \\
(3.83\end{array}$ & $\begin{array}{l}95.33 * * * \\
(3.54)\end{array}$ & $\begin{array}{l}38.20 * * \\
(2.08) \\
\end{array}$ & $\begin{array}{l}25.82 \\
(1.24) \\
\end{array}$ & $\begin{array}{l}4.25^{*} \\
(1.31) \\
\end{array}$ & $\begin{array}{l}85.95 * * * \\
(5.73)\end{array}$ & $\begin{array}{l}25.29 * * * \\
(3.76)\end{array}$ \\
\hline $\begin{array}{l}\text { Total Fertility } \\
\text { Rate }\end{array}$ & $\begin{array}{l}0.38 \\
(0.24 \\
\end{array}$ & $\begin{array}{l}-2.13 \\
(-1.12) \\
\end{array}$ & $\begin{array}{l}3.02 * * \\
(1.95)\end{array}$ & $\begin{array}{l}2.44^{*} \\
(1.49)\end{array}$ & $\begin{array}{l}0.08 \\
(0.05)\end{array}$ & $\begin{array}{l}-1.13^{*} \\
(-1.29)\end{array}$ & $\begin{array}{l}2.49 * * * \\
(4.87)\end{array}$ \\
\hline Log (GDP/capita) & $\begin{array}{l}-6.85 * * * \\
(-3.59)\end{array}$ & $\begin{array}{l}-7.30 * * * \\
(-2.96)\end{array}$ & $\begin{array}{l}-2.89 * * \\
(-1.75)\end{array}$ & $\begin{array}{l}-1.30 \\
(-0.25)\end{array}$ & $\begin{array}{l}-3.95^{*} \\
(-1.30)\end{array}$ & $\begin{array}{l}-6.84 * * * \\
(-3.88)\end{array}$ & $\begin{array}{l}-2.35 * * * \\
(-2.79)\end{array}$ \\
\hline Female Literacy & $\begin{array}{l}-0.19 * \\
(-2.46) \\
\end{array}$ & $\begin{array}{l}-0.23 * * * \\
(-2.83) \\
\end{array}$ & $\begin{array}{l}-0.13^{* * * *} \\
(-2.70)\end{array}$ & $\begin{array}{l}-0.15 * * * \\
(-2.79) \\
\end{array}$ & $\begin{array}{l}-0.01 \\
(-0.04)\end{array}$ & $\begin{array}{l}-0.19 * * * \\
(-3.03)\end{array}$ & $\begin{array}{l}-0.05^{* *} \\
(-1.68)\end{array}$ \\
\hline Undernourished & & $\begin{array}{l}0.23^{* *} \\
(2.19)\end{array}$ & & $\begin{array}{l}0.18^{* *} \\
(2.11)\end{array}$ & $\begin{array}{l}0.16^{* *} \\
(2.20)\end{array}$ & $\begin{array}{l}0.18 * * * \\
(2.62)\end{array}$ & \\
\hline Underweight 1990 & & & & & $\begin{array}{l}-0.17^{*} \\
(-1.43)\end{array}$ & & \\
\hline South Asia & & & $\begin{array}{l}20.22^{* * *} \\
(4.77)\end{array}$ & $\begin{array}{l}19.54^{* * *} \\
(4.01)\end{array}$ & $\begin{array}{l}-1.68 \\
(-0.42)\end{array}$ & & $\begin{array}{l}16.37 * * * \\
(6.16)\end{array}$ \\
\hline East Asia \& Pacific & & & $\begin{array}{l}12.27 * * * \\
(3.65)\end{array}$ & $\begin{array}{l}12.10^{* * *} \\
(3.01)\end{array}$ & $\begin{array}{l}-3.34 \\
(-1.25) \\
\end{array}$ & & $\begin{array}{l}12.70 * * * \\
(6.22)\end{array}$ \\
\hline $\begin{array}{l}\text { Eastern Europe \& } \\
\text { Central Asia }\end{array}$ & & & $\begin{array}{l}-1.52 \\
(-0.37) \\
\end{array}$ & & & & $\begin{array}{l}5.26^{*} \\
(1.49) \\
\end{array}$ \\
\hline Latin America & & & $\begin{array}{l}-2.75 \\
(-1.05)\end{array}$ & $\begin{array}{l}-3.15 \\
(-1.03)\end{array}$ & $\begin{array}{l}-3.07^{*} \\
(-1.51)\end{array}$ & & $\begin{array}{l}0.59 \\
(0.32)\end{array}$ \\
\hline Caribbean & & & $\begin{array}{l}-4.65^{*} \\
(-1.52) \\
\end{array}$ & $\begin{array}{l}-6.44^{* *} \\
(-1.76) \\
\end{array}$ & $\begin{array}{l}-5.05 * * \\
(-2.36) \\
\end{array}$ & & $\begin{array}{l}-3.80 * * \\
(-1.92) \\
\end{array}$ \\
\hline $\begin{array}{l}\text { Middle East \& } \\
\text { North Africa }\end{array}$ & & & $\begin{array}{l}-5.82 * \\
(-1.32)\end{array}$ & $\begin{array}{l}-4.81 \\
(-1.03)\end{array}$ & $\begin{array}{l}-1.78 \\
(-0.36)\end{array}$ & & $\begin{array}{l}-0.73 \\
(-0.46)\end{array}$ \\
\hline Malaria Prevalence & & & & & & & $\begin{array}{l}\text { 7.11*** } \\
(4.17)\end{array}$ \\
\hline Population Density & & & & & & & $\begin{array}{l}0.03 * * * \\
(7.25)\end{array}$ \\
\hline Sanitation Access (\%) & & & & & & & $\begin{array}{l}-0.06^{* *} \\
(-2.33)\end{array}$ \\
\hline $1990-94$ & & & & & & & $\begin{array}{l}-1.05 \\
(-1.18)\end{array}$ \\
\hline $1985-89$ & & & & & & & $\begin{array}{l}-1.97 \\
(-1.26)\end{array}$ \\
\hline Pre-1985 & & & & & & & $\begin{array}{l}-1.74 \\
(-1.10)\end{array}$ \\
\hline $\mathrm{N}$ & 79 & 68 & 79 & 68 & 68 & 128 & 238 \\
\hline Adjusted $\mathrm{R}^{2}$ & 0.565 & 0.569 & 0.788 & 0.771 & 0.166 & 0.515 & 0.819 \\
\hline
\end{tabular}

The first four regressions are based on a cross-section sample for 2000. In the fifth regression, the change in underweight rates between 1990 and 2000 (2000 value minus 1990 value) is regressed on initial levels of undernourishment in 1990 and the change (2000 value minus 1990 value) in the (non-dummy) independent variables. The sixth regression is a random effects regression using data from 1990 and 2000 (the Hausman test suggested the use of random effects as the most efficient estimator; the R-squared here refers to the overall R-squared), and the seventh regression is a pooled (unbalanced) panel regression based on a larger data set. Heteroscedasticity-adjusted t-statistics are shown in parentheses. *, **, *** refers to $90,95 \%$ and $99 \%$ significance levels, respectively (based on a one-tailed test). Sub Saharan Africa is the omitted region (and post-1995 the omitted year dummy in regression 7). 
Table 7: Determinants of the under five mortality rate (child deaths/1000 children 0-5)

\begin{tabular}{|c|c|c|c|c|c|c|c|}
\hline Regression & 1 & 2 & 3 & 4 & 5 & 6 & 7 \\
\hline $\begin{array}{l}\text { Dependent } \\
\text { Variable }\end{array}$ & U5M & U5M & $\begin{array}{l}\text { Change } \\
\text { U5M }\end{array}$ & U5M & U5M & U5M & U5M \\
\hline $\begin{array}{l}\text { Model } \\
\text { Specification }\end{array}$ & $\begin{array}{l}\text { Cross- } \\
\text { Section } \\
(2000)\end{array}$ & $\begin{array}{l}\text { Cross- } \\
\text { Section } \\
(2000)\end{array}$ & $\begin{array}{l}\text { Cross-Section } \\
(2000-1990)\end{array}$ & $\begin{array}{l}\text { Random } \\
\text { Effects Panel } \\
(1990,2000)\end{array}$ & $\begin{array}{l}\text { Random } \\
\text { Effects Panel } \\
(1990,2000)\end{array}$ & $\begin{array}{l}\text { Random } \\
\text { Effects Panel } \\
(1990,2000)\end{array}$ & $\begin{array}{l}\text { Pooled } \\
\text { Panel } \\
(1980-2000)\end{array}$ \\
\hline Constant & $\begin{array}{l}332.50 * * * \\
(7.11)\end{array}$ & $\begin{array}{l}312.90 * * * \\
(4.78)\end{array}$ & $\begin{array}{l}17.02^{* *} \\
(1.68)\end{array}$ & $\begin{array}{l}318.89 * * * \\
(9.87)\end{array}$ & $\begin{array}{l}337.07^{* * *} \\
(6.49)\end{array}$ & $\begin{array}{l}122.19 \\
(1.01)\end{array}$ & $\begin{array}{l}401.96^{* * *} \\
(11.84)\end{array}$ \\
\hline $\begin{array}{l}\text { Total Fertility } \\
\text { Rate }\end{array}$ & $\begin{array}{l}11.08^{* * *} \\
(2.63)\end{array}$ & $\begin{array}{l}9.52 * * \\
(1.81)\end{array}$ & $\begin{array}{l}-3.85 \\
(-0.85)\end{array}$ & $\begin{array}{l}14.47^{* * *} \\
(6.53)\end{array}$ & $\begin{array}{l}14.74 * * * \\
(5.63)\end{array}$ & $\begin{array}{l}15.70^{* * *} \\
(5.70)\end{array}$ & $\begin{array}{l}8.72 * * * \\
(3.47)\end{array}$ \\
\hline $\begin{array}{l}\text { Log (GDP per } \\
\text { capita) }\end{array}$ & $\begin{array}{l}-33.37 * * * \\
(-8.09)\end{array}$ & $\begin{array}{l}-25.68 * * * \\
(-4.47)\end{array}$ & $\begin{array}{l}-15.06^{* *} \\
(-1.84)\end{array}$ & $\begin{array}{l}-30.21 * * * \\
(-7.91)\end{array}$ & $\begin{array}{l}-36.40 * * * \\
(-6.60)\end{array}$ & $\begin{array}{l}-18.07 * * \\
(-1.67)\end{array}$ & $\begin{array}{l}-31.58 * * * \\
(-8.30)\end{array}$ \\
\hline Female Literacy & $\begin{array}{l}-0.51 * * * \\
(-2.32)\end{array}$ & $\begin{array}{l}-0.74 * * * \\
(-3.28)\end{array}$ & $\begin{array}{l}0.66^{*} \\
(1.34)\end{array}$ & $\begin{array}{l}-0.46^{* * *} \\
(-3.13)\end{array}$ & $\begin{array}{l}-0.43^{* * * *} \\
(-2.52)\end{array}$ & $\begin{array}{l}-0.06 \\
(-0.26)\end{array}$ & $\begin{array}{l}-0.41 * * * \\
(-2.24)\end{array}$ \\
\hline HIVprevalenve & $\begin{array}{l}1.97 * * * \\
(5.97)\end{array}$ & $\begin{array}{l}1.26^{* * *} \\
(2.94)\end{array}$ & $\begin{array}{l}0.65^{* * *} \\
(2.42)\end{array}$ & $\begin{array}{l}1.36^{* * *} \\
(6.53)\end{array}$ & $\begin{array}{l}1.40^{* * *} \\
(5.62)\end{array}$ & $\begin{array}{l}1.38^{* * *} \\
(5.70)\end{array}$ & \\
\hline Underweight & & & & & $\begin{array}{l}0.002 \\
(0.01) \\
\end{array}$ & & \\
\hline Underweighthat & & & & & & $\begin{array}{l}2.23^{* *} \\
(1.92)\end{array}$ & \\
\hline U5M 1990 & & & $\begin{array}{l}-0.25 * * * \\
(-5.84)\end{array}$ & & & & \\
\hline South Asia & & $\begin{array}{l}-41.91 * * * \\
(-3.49)\end{array}$ & $\begin{array}{l}-28.89 * * * \\
(-3.50)\end{array}$ & & & & $\begin{array}{l}-17.59 * * \\
(-1.67)\end{array}$ \\
\hline $\begin{array}{l}\text { East Asia and } \\
\text { Pacific }\end{array}$ & & $\begin{array}{l}-19.44 * \\
(-1.57)\end{array}$ & $\begin{array}{l}-27.92^{* * *} \\
(-3.55)\end{array}$ & & & & $\begin{array}{l}-6.02 \\
(-0.60)\end{array}$ \\
\hline $\begin{array}{l}\text { Eastern Europe } \\
\text { \& Central Asia }\end{array}$ & & $\begin{array}{l}-6.19 \\
(-0.40\end{array}$ & $\begin{array}{l}-18.91^{*} \\
(-1.45)\end{array}$ & & & & $\begin{array}{l}-3.85 \\
(-0.32)\end{array}$ \\
\hline Latin America & & $\begin{array}{l}-25.87 * * \\
(-2.13)\end{array}$ & $\begin{array}{l}-25.30 * * * \\
(-3.34)\end{array}$ & & & & $\begin{array}{l}-15.53^{* *} \\
(-2.11)\end{array}$ \\
\hline Caribbean & & $\begin{array}{l}-19.36 * * \\
(-1.72)\end{array}$ & $\begin{array}{l}-19.68 * * * \\
(-2.87)\end{array}$ & & & & $\begin{array}{l}-37.28 * * * \\
(-3.92)\end{array}$ \\
\hline $\begin{array}{l}\text { Middle East \& } \\
\text { North Africa }\end{array}$ & & $\begin{array}{l}-40.88^{* * *} \\
(-3.38)\end{array}$ & $\begin{array}{l}-38.06 * * * \\
(-3.96)\end{array}$ & & & & $\begin{array}{l}-20.88^{* *} \\
(-2.14)\end{array}$ \\
\hline $\begin{array}{l}\text { Malaria } \\
\text { Prevalence }\end{array}$ & & & & & & & $\begin{array}{l}-12.42 \\
(-1.21) \\
\end{array}$ \\
\hline $\begin{array}{l}\text { Sanitation } \\
\text { Access }\end{array}$ & & & & & & & $\begin{array}{l}-0.19^{*} \\
(-1.51)\end{array}$ \\
\hline $\begin{array}{l}\text { Immunization } \\
\text { Rates (DPT) }\end{array}$ & & & & & & & $\begin{array}{l}-0.74 * * * \\
(-3.69)\end{array}$ \\
\hline 1990-94 & & & & & & & $\begin{array}{l}-4.82 \\
(-0.91)\end{array}$ \\
\hline 1985-89 & & & & & & & $\begin{array}{l}-0.21 \\
(-0.03)\end{array}$ \\
\hline Pre 1985 & & & & & & & $\begin{array}{l}25.43 \\
(0.99)\end{array}$ \\
\hline $\mathrm{N}$ & 82 & 82 & 80 & 160 & 122 & 122 & 205 \\
\hline Adjusted $\mathrm{R}^{2}$ & 0.858 & 0.883 & 0.535 & 0.857 & 0.864 & 0.864 & 0.812 \\
\hline
\end{tabular}

The first two regressions are based on a cross-section sample for 2000. In the third regression, the change in under-five mortality rates between 1990 and 2000 is regressed on initial levels of under-five mortality in 1990 and the change in the (non-dummy) independent variables. Regressions 4-6 are random effects regression using data from 1990 and 2000 (the Hausman test suggested the use of random effects as the most efficient estimator; the R-squared here refers to the overall R-squared), and the sixth regression is a pooled (unbalanced) panel regression based on a larger data set. Underweighthat refers to predicted underweight rates using regressions 6 of Table 6. Heteroscedasticity-adjusted tstatistics are shown in parentheses. *, **, *** refers to $90,95 \%$ and $99 \%$ significance levels, respectively (based on a one-tailed test). Sub Saharan Africa is the omitted region (and post-1995 the omitted year dummy in regression 7). 
Figure 1: Undernourishment and Childhood Underweight in 2000

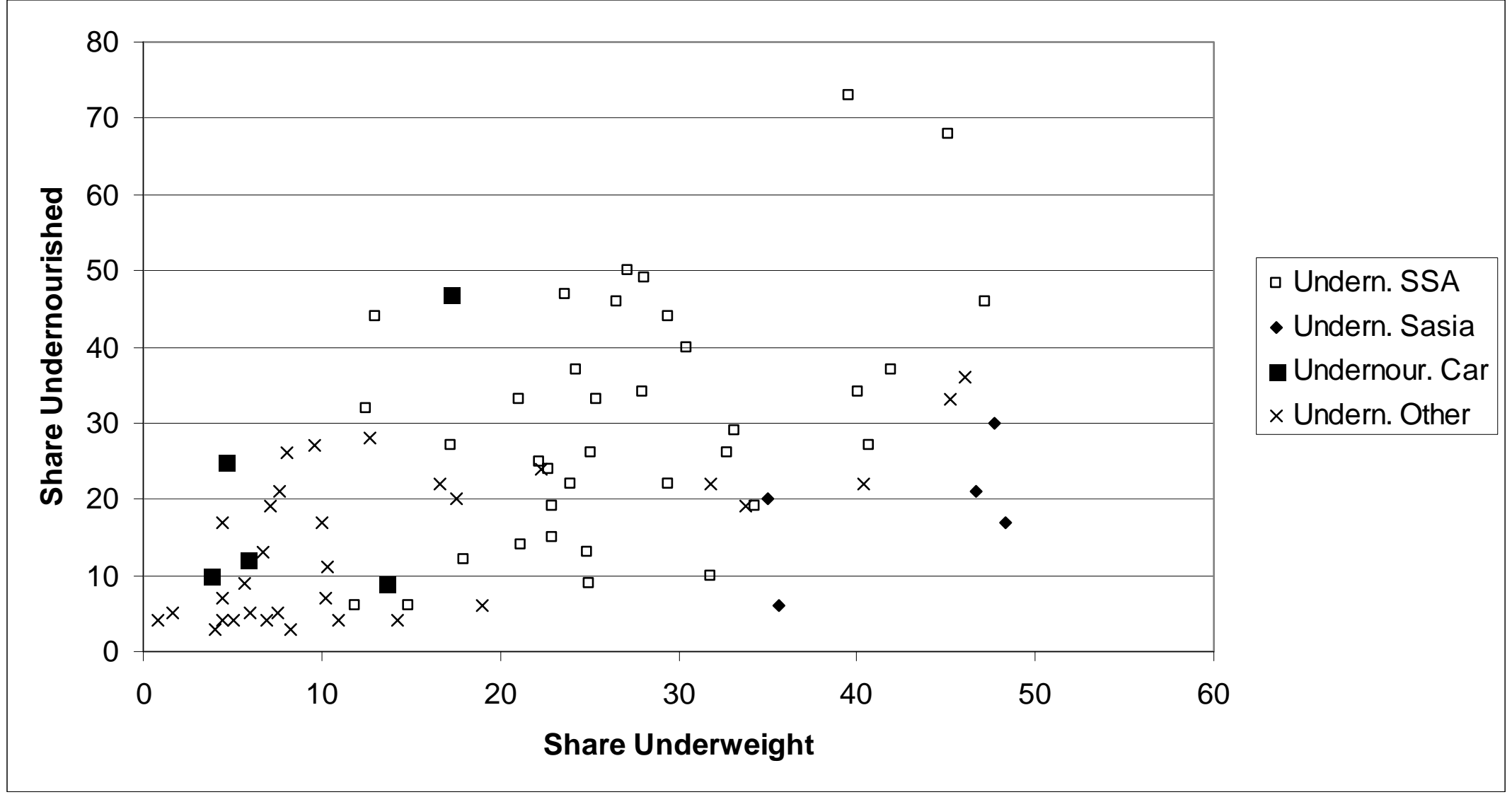


Figure 2: Childhood underweight and under 5 mortality rates 2000

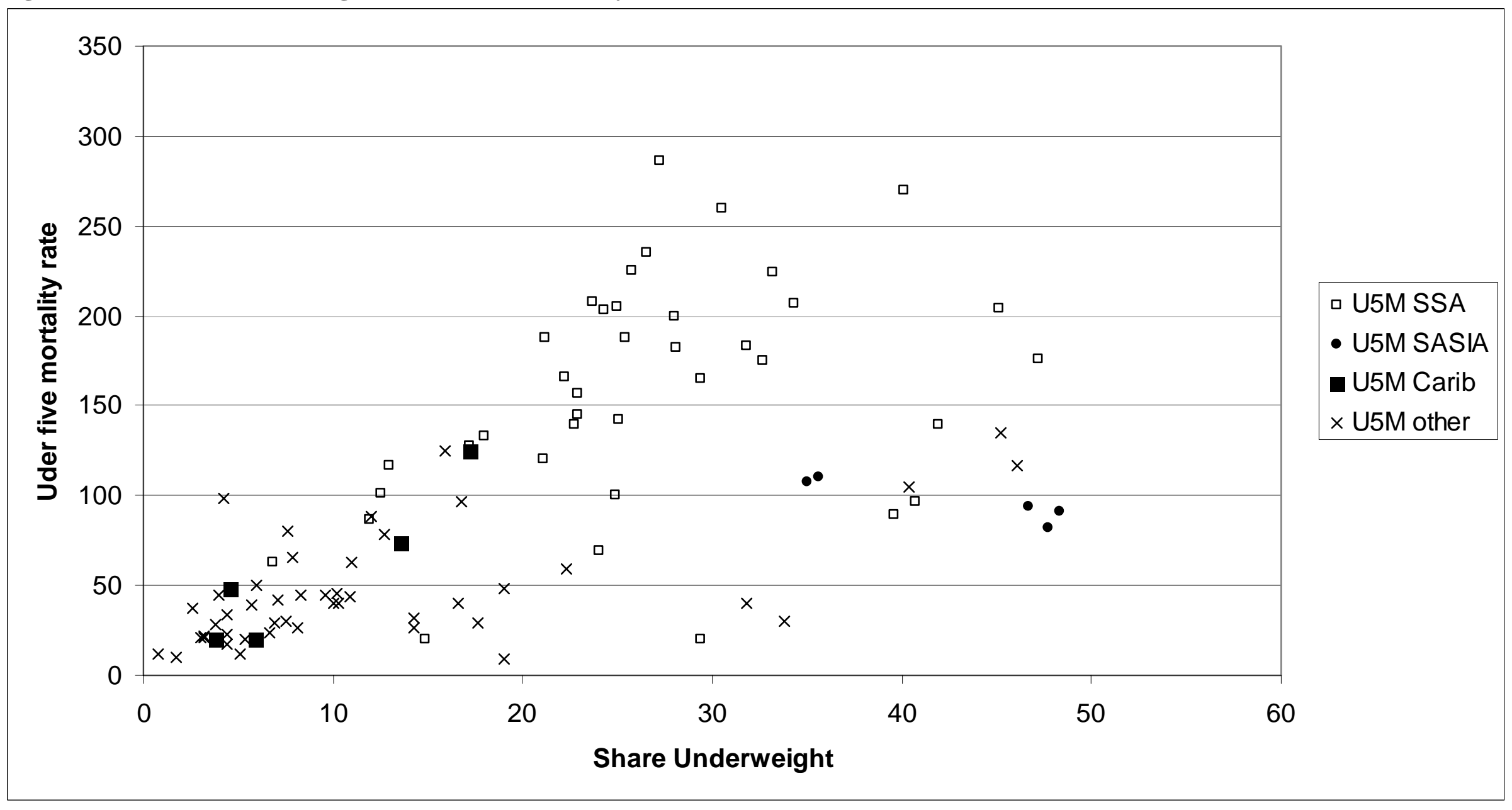

